

\section{NOTICE.}

"This report wis prepared as en eccount of wosk iponsored by the United States Government. Ne ither the United States nor the United States Eneriy Research 1 Development Admisistration, nor any of their employes, nor any of their contractors, subcontractors, of thuit employes, mikes any weficity, express of implisd, of ussumes sny legal libitity of responalbility for the accuracy. compitenes or uséfulnte "of eny Information, opperatus, product or procese dieclosed, of represents that its uso would not inftinge privately-oinned rithis"

Printed in the United States of America Available from

National Technical Inforination Service

U.S, Department of Comimerce 5285 Port Royal Road Springfield, Virginia 22151

Price: Printed Copy $\$$ *; Microfiche $\$ 2.25$

$$
\begin{gathered}
\text { * Pages } \\
\begin{array}{c}
1-50 \\
51-150 \\
151-325 \\
326-500 \\
501-1000
\end{array}
\end{gathered}
$$$$
\text { NTIS }
$$$$
\text { Selling Price }
$$$$
\$ 4,00
$$$$
\$ 5.45
$$$$
\$ 7.60 \text {. }
$$ 


\section{논 \\ LAWRENCE IVERMORE LABORATORY \\ Unikirstyof Caltomia/ Livemore, Caftomia/94550}

\section{UCRL-51916 \\ DIAMOND-TURNING HP-21 BERYLLIUM TO ACHIEVE AN OPTICAL SURFACE}

D. K. Allen, H. W. Hauschildt, and J. B. Bryan

MS. date: September 25, 1975

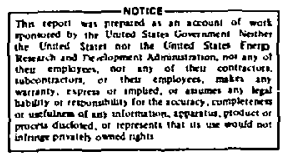




\section{Contents}

Abstract . . . . . . . . . . . . . . . . . . . . . . . . 1

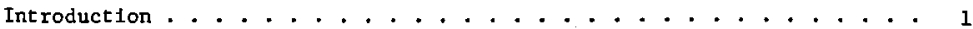

Materlal . . . . . . . . . . . . . . . . . . . . . . 2

Equipment and Tooling . . . . . . . . . . . . . . . . . . . . 3

Hardinge Frecision Lathe . . . . . . . . . . . . . . . . . . 3

Cutting Tools... . . . . . . . . . . . . . . . . . . . 4

Cutting Fluids . . . . . . . . . . . . . . . . . . . . . 4

Test Proredure . . . . . . . . . . . . . . . . . . . . . . . 6

Facling Cuts - Prellminary Tests . . . . . . . . . . . . . . . 6

Longltudinal Turning Cuts - Wear Tests . . . . . . . . . . . . 6

Facing of DIsk Speclmene . . . . . . . . . . . . . . . . . 6

Test Data and Discussion of kesults . . . . . . . . . . . . . . 7

Faclng Cuts - Prellminary Tests . . . . . . . . . . . . . . 7

Longitudinal Turning Cuts - Wear Tests . . . . . . . . . . . . . 15

Facing Cuts on Disk Speclmens . . . . . . . . . . . . . . . . . 39

Conniustons . . . . . . . . . . . . . . . . . . . . . . 47

Recommendations ........................... . 49

References . . . . . . . . . . . . . . . . . . . . . . 50

Append1y A. HP-2l Log Analysis . . . . . . . . . . . . . . . . 51

Append1x B. HP-21 Radiograph and Nondestructive Test Report. . . . . . 52

Appendix C. Specifications and Analysis of Pure Beryllium . . . . . . 53

Appendtx D. Results of Cuts and Tests... . . . . . . . . . . . 56 


\title{
DIAMOND-TURNING HP-21 BERYLLIUM TO ACHIEVE AN OPTICAL SURFACE
}

\begin{abstract}
The Investigation of diamond turning on beryllium was made in anticipation of obtaining an optical. finish. Although results of past experiences were poor, it was declded to continue diamond turning on beryllium beyond inftial fatlures. By ctuanging speed and using coolant, partial success was achleved. Tool wear was the major problem. Tests were made to establish and plot wear as a function of cutiling speed and t1me. Slower speeds did cause lower wear rates, but at no time did wear reach an acceptable level.

The machine, tools, and procedure used were chosen based on the resulz of our prelimfnazy attempts and on previous experience. It was unnecessary to use an alr-bearing spindle because cool fallure governed the best finish that coild be expesiced. All tools of dfamond composition, whether single cryatal or polycryatalline, wore at unacceptable rates. Baged on present technology It must be concluded that beryllium cannot be feasibly diamond turned to achleve an optical fintsh.
\end{abstract}

\section{Introduction}

The United States A1r Force, in confunction with Honeywel1, Inc., Radiation Center of Lexington, Massachusetts, is engaged In establishIng new or Improved fabricacion and assembly techniques for avionics systems and subsystems. Thlo study Includes an investigation of diamondtuining technlques for achleving optical finlshing, Kaweck ilP-2:. beryll1um.*

\footnotetext{
* Reference to a company or product name does not 1mply approval or recommendation of the product by the University of Californta or the U,S. Energy Research \& Development Adintistration to the exclusion of others that may be suttable.
} 
Because of extenstve prior experience with diamond-turning techniques and the avallability of speclalized equipment, Lawrence lifermore Laboratory has been asked to undertake the machining investigation. The objective of this investigation is to obtain an optical surface on an HP-2l beryll1um rest specimen, using diamond-turning techniques. In

the event th.t an optical surface cannot be generated by thts method, complete documentation wil1 be furnished to the sponsor to aid in subsequent investigations.

\section{Material}

The test material used in this Investigation is an HP-21 beryllium rod, $1.5 \mathrm{in}$. In diameter by $3 \mathrm{in}$. long, supplied by Honeywe11. The mechanical properties of this material are :
a) Litimate tensile strength = 45,000 psi
b) Yield strength $=35,000$ pst
c) Elongation $=2 \%$ in 1 in.
d) Grain size is listed as not to exceed $25 \mu$

The chemical composition for HP-2l is given in Table 1.

As shown $1 \mathrm{n}$ Table 1 there is a considerable number of alloy elements and impurity matals in the HP-21 composition. Because of severe dia. mond wear problems the HP-21 beryllfum sas examined ly a $14-\mathrm{kV} x$ ray to determine the distribution and size of Impurfty elements as a posstble explanation of the rapid diamond
Table 1. Chemical composition of HP-21 beryll1um.

$\begin{array}{lcc}\text { Beryllium assay } & \% \text { minimum } & 98.0 \\ \text { Beryllium oxlde } & \% \text { maximum } & 2.0 \\ \text { Aluminum } & \% \text { maximum } & 0.15 \\ \text { Carbon } & \% \text { maximum } & 0.15 \\ \text { Iron } & \% \text { maximum } & 0.18 \\ \text { Magnesium } & \% \text { maximum } & 0.08 \\ \text { S1licon } & \% \text { maximum } & 0.03 \\ \text { Other metallic } & \% \text { maximum } & 0.0 \% \\ \text { impurities, each } & & \end{array}$

Note: The minimurn bulk deasity is given at $1.84 \mathrm{~g} / \mathrm{cm}^{3}$. (Theoretical densit, is $1.85 \mathrm{~g} / \mathrm{cm}^{3}$.)

wear. Results of this examination are In Append $1 x$ B. It car be seen that a large number of Impuricy elements are distributed throughout the material. Although an Investigation was not made to determire the actual form in which these elentents were present, thoy are thought to be combined as beryllium carbide, $\mathrm{AlFeBe}_{4}$, and $\mathrm{FePe}_{11}$. 
To give some ldea of the abrasiveness of these hard intermetallic compounds, the following figures ate cited: diamond registers 10 oil Nohs' scale, berylifum oxide 7.8, aluminum oxide 9+, and beryllium carbide 9+. Ail these partjcles are very ahrasive, and some are used as lapping compounds.

Investigation of single berylifum crystals reveal the extreme antsotropy present. For exniple, prellminary compression tests by London et al. ${ }^{1}$ and $\mathrm{McLean}{ }^{2}$ indicate that plastic flow and/or fracture occur $3 \tau$ stresses on the crder of $300,000 \mathrm{psI}$ at roon temperature along the $c$ axis. However, shear stresyes required to initiate fracture along the basal plane are only about one-thousandth of that necessary for c-axis fracture. The above figures are for single crystals, but it could be expected that when machining polycrustalline beryllium, a wide variation of mechantcal shear stresses would be encountered due to differences in grain orientation.

\section{Equipment and iooling}

HARDINGE PRECISION LATHE

We used a Hárd'nge model HLVI * 11, 1.5-hp precision lathe. This lathe was chosen because of 1 ts excellent spindle bearings and $i$ ts ability zo achieve optical finishes. It is equipped with an infinitely variable spindle speed and carriage feed drive ldeally sulted for atachfr:ing studies. The minimum speed is $30 \mathrm{kpm}$, and the minimum crossfeed rate is $0.130 \mathrm{in.} / \mathrm{mir}$.

The lathe was enclosed in a protective hood produced by Allied Engineering and Production Corporation to contain any beryllium chips produced during tine test. A highvelocity air syster pulled all beryllium particies into a spectal filtering system. The lathe and hood setup are shown in Fig. 1.

Pendirg the successful outcome of inftial test cuts, the Noore diamond-turning machine, using an alr-bearing spindle, was to be used to achieve the ultimate in precision turning. However, because of problems that will be discussed later, this machine was not reoutred to carry out the test. 


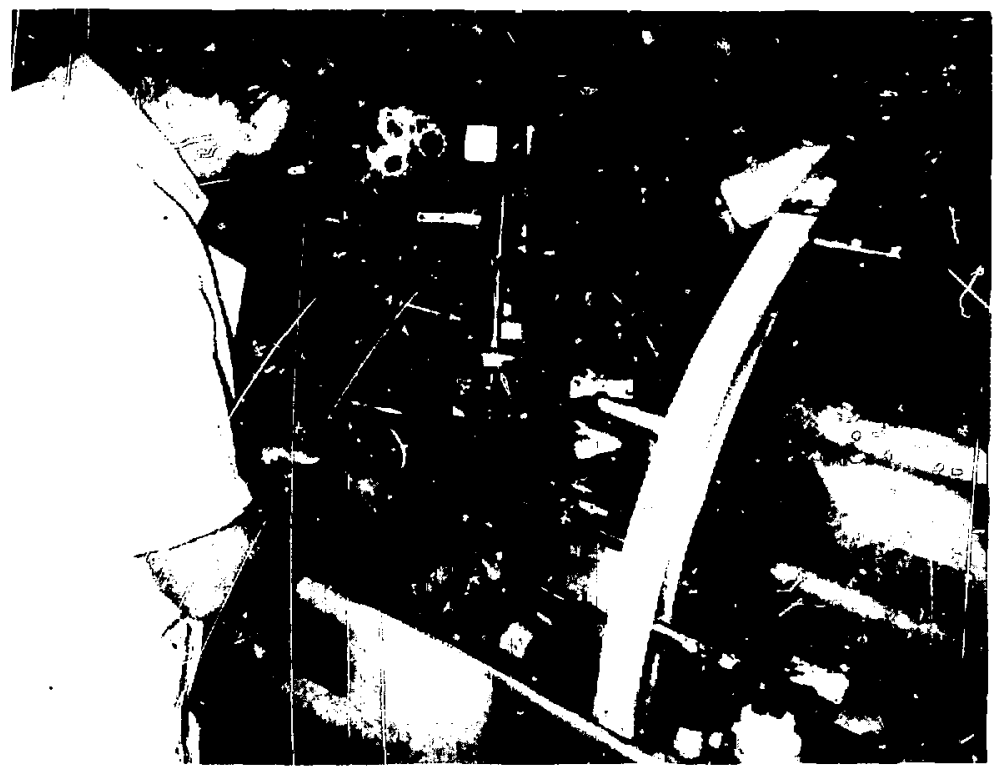

F1g. 1. Harding Lathe and enclosure.

\section{CUTTING FLUIDS}

Several cutting fluids were also

\section{CUTTING TOOLS}

Although this study primariiny Investigated diamond turning on beryllium, other turning tools were also trled because of the rapld wear on diamond. The various tool materlals used are shown in Table 2. They include single-crystal diamond, polycrystalline diamond, carbfde, and ceramic tools. used to accertain their effect in reducing tool wear. These fluids included liquid Freon TF (trichlorotrifluoroethane), Freon spray (dichlorodifluoromethane), and perchloroethylene. The fluids were Intenced to reduce both the temperature at the tool chip interface and friction, and a steady flow of fluid was maintained on th? tool by a spectal dispenser (Figs. 1 and 2). 
Table 2. Tool materials used in beryllium machining study.

Tool types

Nose radius, in.

Clearance angle

Moore single-crysta?. diamond

Megadiamund, polycrystaIline diamond

907 carb1de

Co-6 ceramic

Citco single-crystal diamond
0.030

0.015

0.030

0.030

0.030 $4^{\circ} 40^{\prime}$ to $9^{\circ} 38^{\prime}$

$4^{\circ} 20^{\prime}$

$7^{\circ} 40^{\prime}$

$4^{\circ} 40^{\prime}$

j.

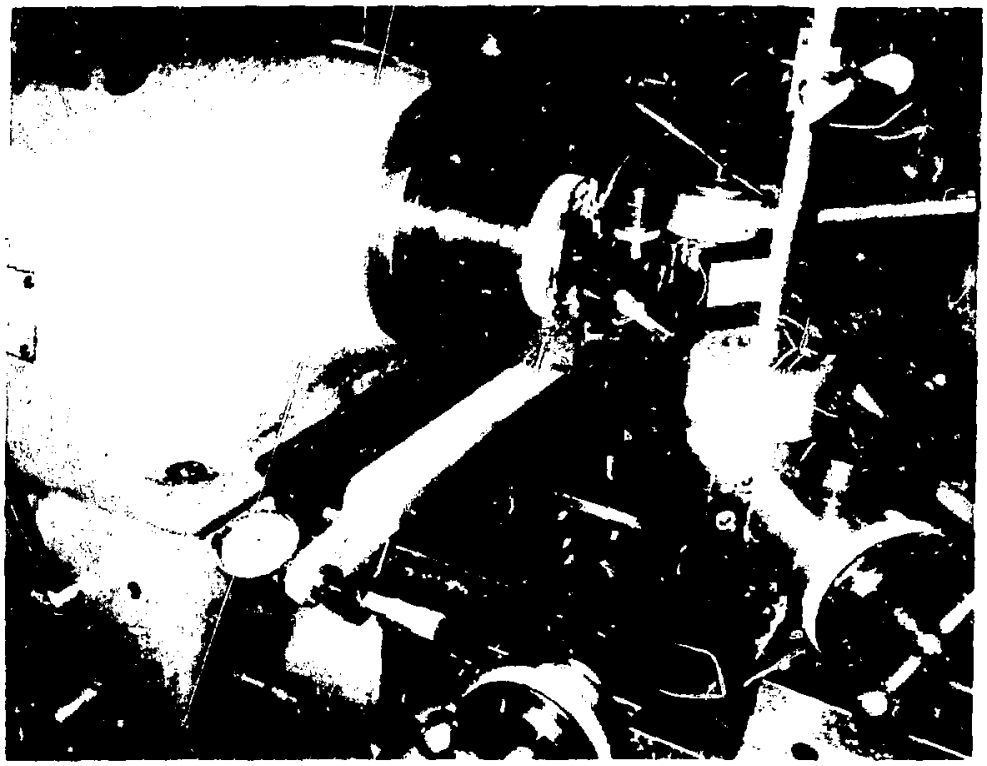

Fig. 2. Collet setup for machining disks. 


\section{Test Prucedure}

The basic procedise followed in evaluating the turning capabilicies of varlous tool materials on beryllium was as follows.

FACING CUTS - PRELININ. RY TESTS

The beryllium teat log was mounted in a four-jaw chuck in the test lathe, and the diamond tool was held in an Aloris tool holder as shown in Fig. 2. A center hole was drilled in the rest specimen to overcome problems of establishing exact se:-height. The tool was fed radially olstward from the center of the test specimen. A Port-1-Tak was used to get exaci spindle rpm, and a stopwatch was used to check the crossslide feed rate. In most instances a $0.001-1 \pi$. $(0.0254-\mathrm{mm})$ depth of cut was used with a feed rate of approximately $0.001 \mathrm{in./ \textrm {rev } .}(0.0254 \mathrm{mom} /$ rev.).

During the 1nitial cut, the dianond-turned surface appeared to be of marginal success. However, we observed that significant tool wear had occurred during the cut. As a result of this and several other test face cus, we declded that a serles of cuts should be taken on the periphery of the workplece to malataln a constant surface feed and to evaluato the tool wear ratos at varlous cutting speeds. We used frusn TF cutting flu: on the final test face cut to reduce temperature and friction, and it proved to be helpful in achieving a better finish.

LONGITUDINAL TURNING CUTS - WFAR TESTS

These cuts were made to maintain constant surface speeds for establishing tool wear rates. The turning test involved operating the lathe at various speeds from 30 to $2000 \mathrm{rpm}$. Feed rates were selected to maintain $0.001 \mathrm{in.} / \mathrm{rev}$. (C.0254 mo/rev.). To minimize the difficulty of accurately maincaining the low feed ratks at low spindle rpm's, we ajded a speciai varlable-speed drive to chr carriage. This consisted of a gear-reduction Bodine motor driven by a Miniark varlable-speed control unit. The carriage was driven through a double o-ring belt-drive system.

\section{FACING OF DISK SPECIMENS}

To provide a series of historical samples, 0.25-1n.-thick (6.35-пmthick) spectmens were parted off from the $3-i n$. (76.2-mm) test $10 g$, and a spectal soft-jaw collet chuck was used to hold them (Fig. 2). It was 
on these specimens that the effects of varfous tool materlals were

In testigated.

Preliminary tests showed it :0 be unnecessary to feed at rates of less than $0.001 \mathrm{in.} / \mathrm{rev} .(0.0254 \mathrm{~mm} /$ rev.). The minfum feed the machine drive system could produce was 0.130 in./min (3.302 $\mathrm{mm} / \mathrm{m} 1 \mathrm{n})$. At $100 \mathrm{rpm}$ his would achleve $0.0013 \mathrm{in.} / \mathrm{rev}$. $(0.033 \mathrm{~mm} / \mathrm{rev}$ ) , a suitable feed rate ior these tests.

\section{Test Data and Discussion of Results}

FACING CUTS - PRELLMINARY TESTS

Fir the first cut, the beryllium test $\log$ was mounted in a four-jaw chuck. The test log was drilled with a No. 2 center drill, the face wes cleaneo up with a carhide tool, and the edge was chamfered. Mocrs diamond tool it! -44 was mounted in the Aloris tool lulder. The spindle speed tas set at $900 \mathrm{rpm}$, the feed rate at $0.00035 \mathrm{in.} / \mathrm{rev}$. (0.009 mm/rev.), that is, $0.320 \mathrm{in.} / \mathrm{mfn}(8.128 \mathrm{~mm} / \mathrm{min})$, and the dep at of cur at $0.001 \mathrm{in}$. $(0.0254 \mathrm{~mm})$. This should provide a 0.5 -jin. (0.0127-j) peak-to-va11zy $(P / i)$ theoretical finish.

During the first portion of the cut, out to about a $1 \cdot-111 .(25.4 \mathrm{~mm})$ diameter, the machined surface was reflective. The remainder of the machined surface was torn. The tool was removed and examined by microscope. Approximately 0.002 to 0.003 1n. $(0.0508$ to $0.0762 \mathrm{~mm})$ flank weat Iand was present (Figs. 3a, 3b, and $3 c)$.

Test Cut No. 2

The work was then re-inserted into the chuck, and a second pass was made at $0.130 \mathrm{ln} . / \mathrm{mln}$ (3.302 oun/min) feed rate and at $375 \mathrm{rpm}$. The intent of this sacond cut was to help ascertain the predominant faflure mode on the diamond rool (i.e., did the thermal mode or thí abrasive mode predominate?). A surface frotile trace of the test log face was made revealing the rapid diamond wear rate. During the first 25 revolutions of the cut, the surface roughness was in the 3- to 5-Hin. (0.07- to 0.127- 4 ) range, but rapidly deteriorated to a rough, torn surface appearance. This trace is shown in Fig. 4.

The microscopic sxamination of the workplece surface is shown in Figs. 5a and 5b. Figure 5a was taker: at the beginning of the cut and Fig. 


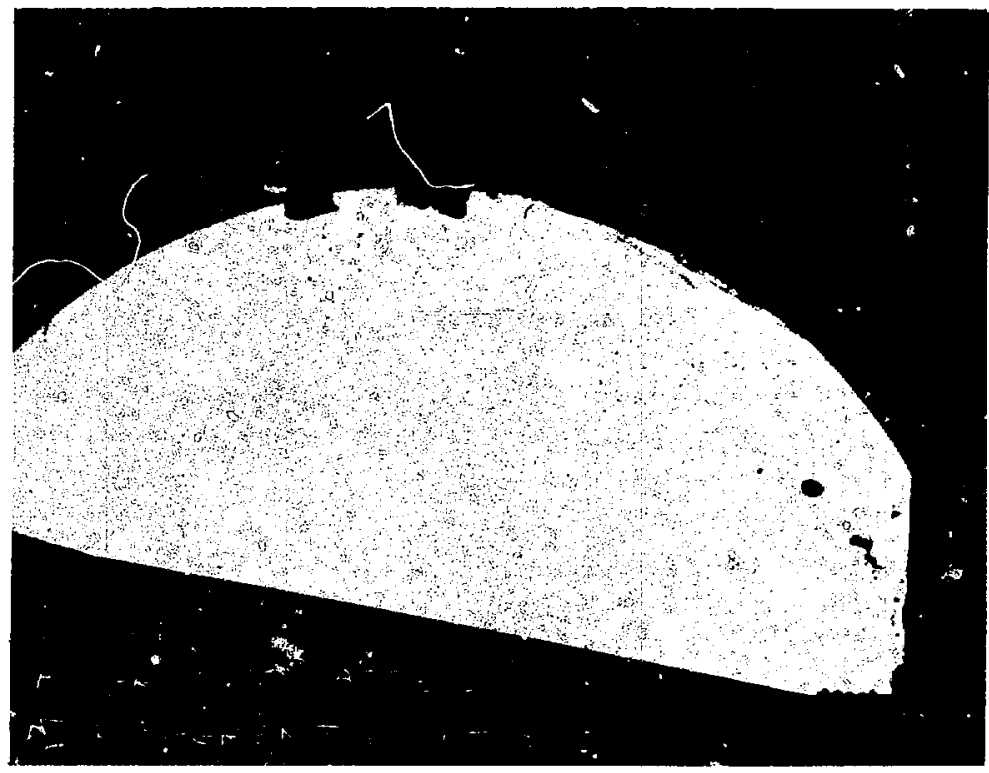

FIg. 3. Moore dtamond tool $\|_{L}-44$. (a) Top view, $121 \mathrm{x}$.

$5 \mathrm{~b}$ was taken $0.125 \mathrm{in} .(3.175 \mathrm{~mm})$ from the end of the cut. Figure 5 a confirms the 3- to 5-jin. (0.07- to $0.27-\mu) P / V$ roughness shown on the profile trace, while F1g. $5 b$ shows a severe form error due to excessive tool wear and pressure. The tool was also examined under the microscope and revealed a series of parallel grooves in the wear flank. These grooves, known as "Pekelharıng grooves," have a spacing between them approximating the feed rate (F1g. 3d). The mechanism of tool failure is not known at this time, but it appears to be primartly an abrasive type wear.

Test Cut No.3

Tape was placed over the first end to protect $1 t$ for later microscoplc examination, and the workpiece was reversed in the chuck. A new 


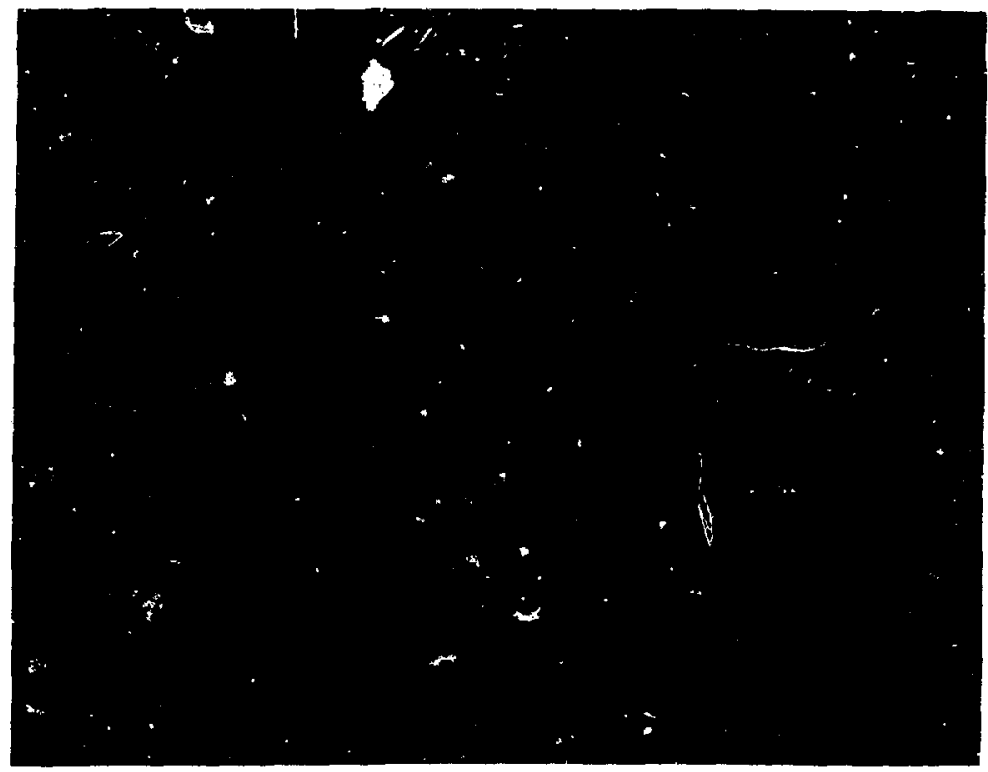

Fig. 3. Moore diamond tool kL-44. (b) Front vlew showing flank wear, $337 x$.

center hole was drilled and a cleanup cut was taken with a carbide cutting tool. A new diamond tool was used (Moore $\sharp L^{\prime} \cdot ?$ ). Feed rate was 0.130 in./min ( $3.302 \mathrm{~mm} / \mathrm{min})$, speed 375 rpm, and depth of cut $0.001 \mathrm{in}$. $(0.0254 \mathrm{mun})$. The intent of this cut was to ascertain repeatabllity of the test using a new diamond tool.

Following this test the specimen was examtned under the microscope, and photomicrographs of the specimen were taken. Clevite suzface flnish analyzer readings were also taken for both ends of the specimen and correlated with the interferometric photographs. This test definitely conflrmed the repeatability of the tool fallure mode, (Figs. 6a, 6b, and 7). After some discussion we declded that both cutting temperature and abrasiveness of the workplece may 


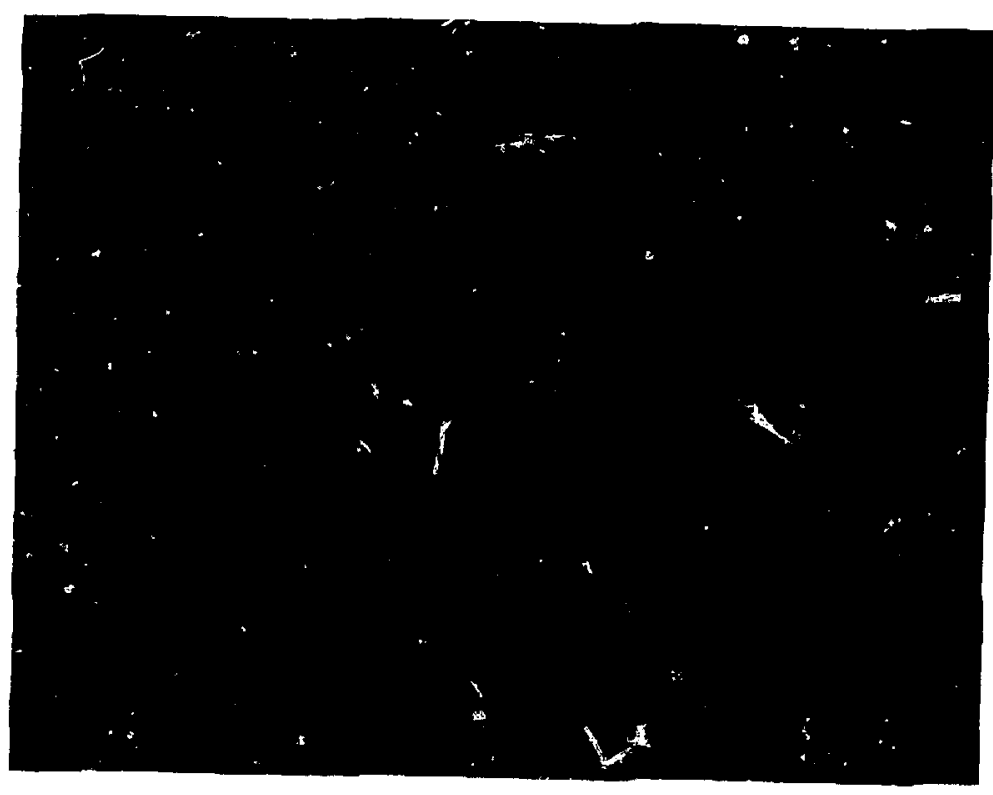

Fig. 3. Moore diamond tool $\$ L-44$. (c) Wear land caused by first pass, $611 \mathrm{X}$.

be the cause of rapid tool wear. A series of experiments was set up in which 1 was felt important to reduce speed, apply cutting fluid, and check the effects of tool temperature and abrasiveness.

\section{Test Cut No. 4}

A cut was made using carbide grade 907 to compare the wear rates of carbide tools with that of diamond. Two cuts were taken, one on each end of the workpiece. These were later evaluated, and we found that a finish of 30 to $40 \mathrm{\mu in}$. $(0.76$ to $1.01 \mu) P / V$ was obtained. This finish, while good, was not of optical quality. Wear rate on the carbjde was approxtmately one-half that of the single-crystal diamond. Cutting conditions for the carbide tool were 


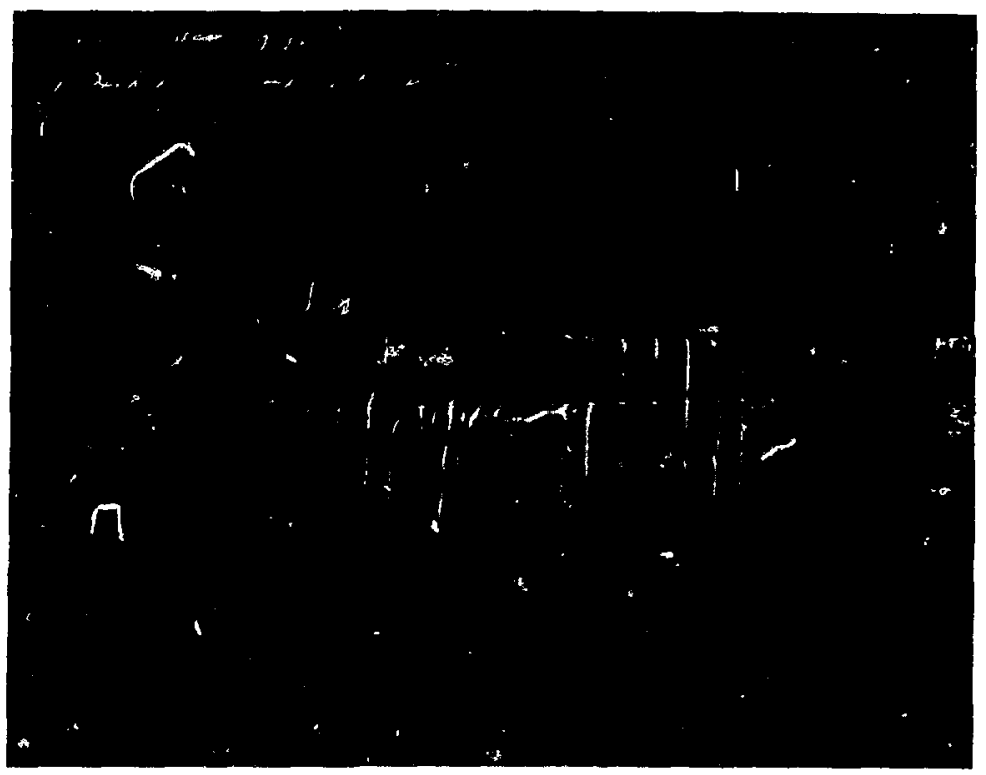

Fig. 3. Moore dianond tool \$1 44. (d) Wear land caused by second pass, 611x.

$750 \mathrm{rpm}$ speed and 0.600 in./min $(15.24 \mathrm{~mm} / \mathrm{min})$ feed rate. No cutting fluid was used with this cut. Tool flank wear was 0.0016 in. (Figs. 8 and $9 \mathrm{~b})$.

\section{Test Cut No. 5}

The next cut was made to ascertatn the combined effects of temperatureand friction-reducing methods on diamond turning as Indicated previously. A slow rpm with a coolant was used. The speed was $100 \mathrm{rpm}$, the feed rate was standardized at 0.130 In. $/ \mathrm{min}$ ( $3.302 \mathrm{~mm} / \mathrm{min}$ ), and a Moore diamond tool (fF-4) was used. The depth of cut was approximately 0.0005 in. $(0.0127 \mathrm{~mm})$. The cutting fluid Freon TF was used. The specimen and the diamond tool were examined for flank wear after the cut. Flank wear 


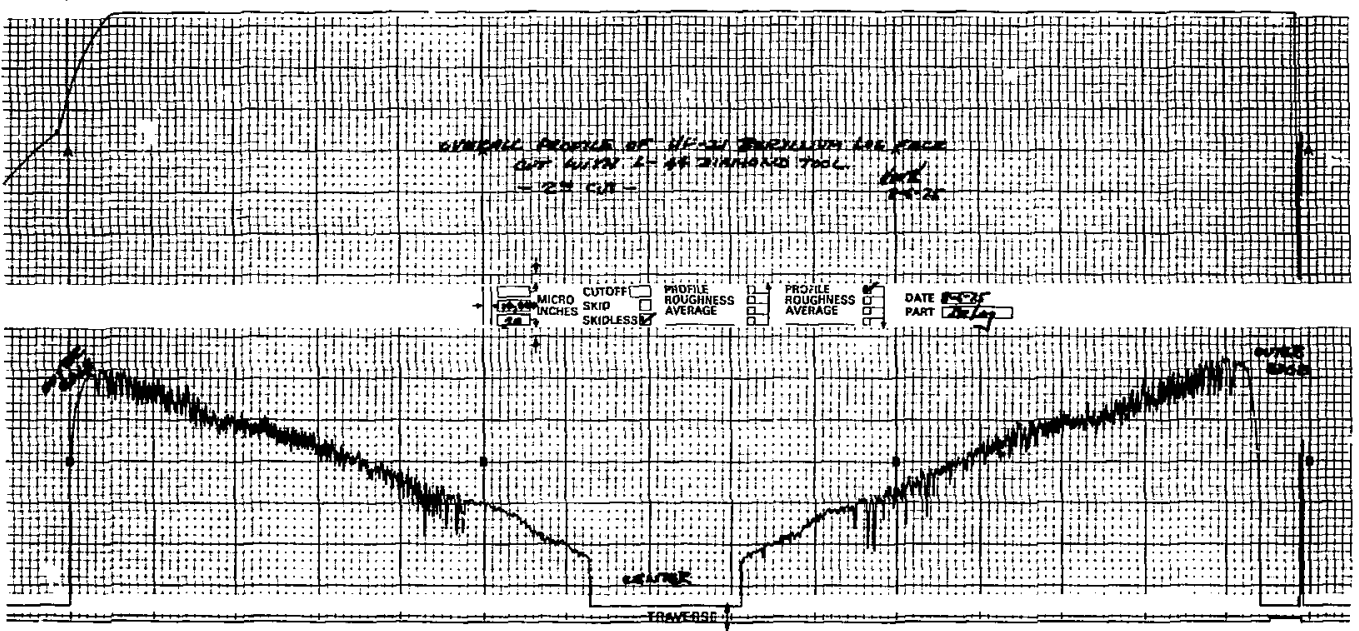

F1g. 4. Trace of face cut with tool 非-44; second pass, no coolant. 


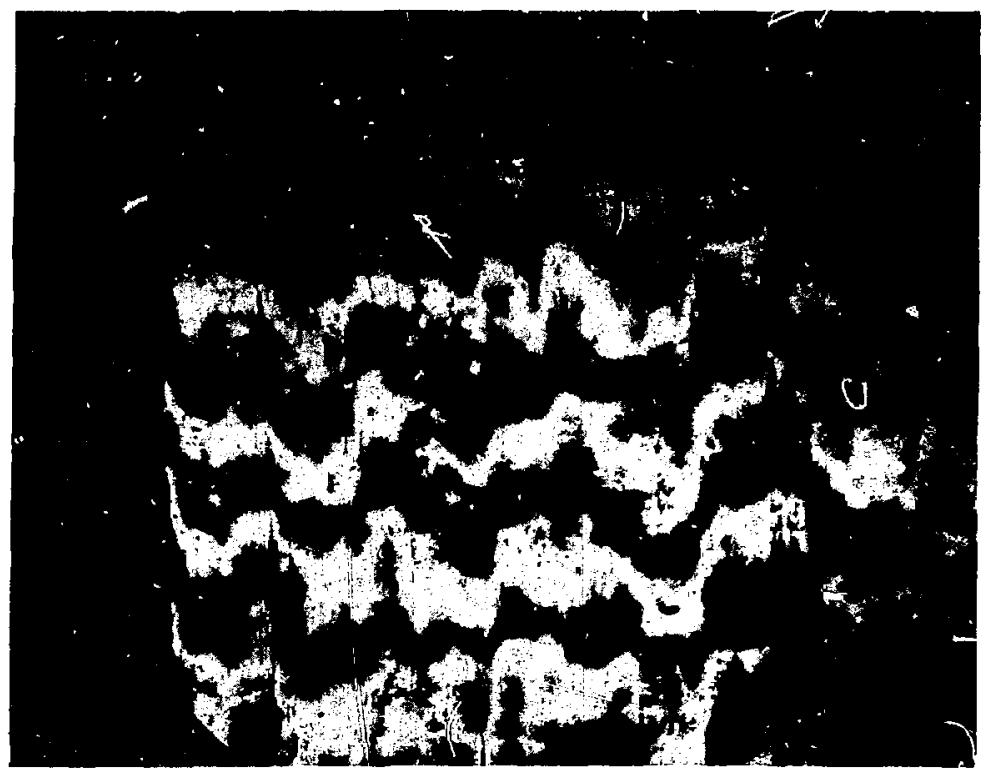

FIg. 5. Interference photomlcrographs of Test Cut No, 2. (a) Finish at start of cut, $337 \mathrm{x}$.

was found to be about $0.0018 \mathrm{in}$.

$(0.04572 \mathrm{~mm})$, and a $2-$ to $30-\mu 1 \mathrm{n}$.

(0.05- to $0.76-\mu) \mathrm{P} / \mathrm{V}$ surface finlsh was achleved (FIgs 9a, 10a, 10b, 11a, $11 b$, and 12).

Test Cut No, 6

We learned from Bill Pope of the Megadiamond Corporation that diamond begins to graphitize at approximately $1200^{\circ} \mathrm{C}$ or below. We also learned that beryllium acts as a catalyst in promoting graphitization. isis, along with information on grinding steel with diamond tools, ${ }^{3-5}$ led to the formulation of the theory that the fallure mechanism when nachining beryllium is graphitization. The diamond wear surface appeared to graphitize, after which it was rapioly abraded by hard particles and the beryllium chip. Consequently, tests wose made at reduced temperatures to help reduce the rate of diamond graphitization and flank wear. 


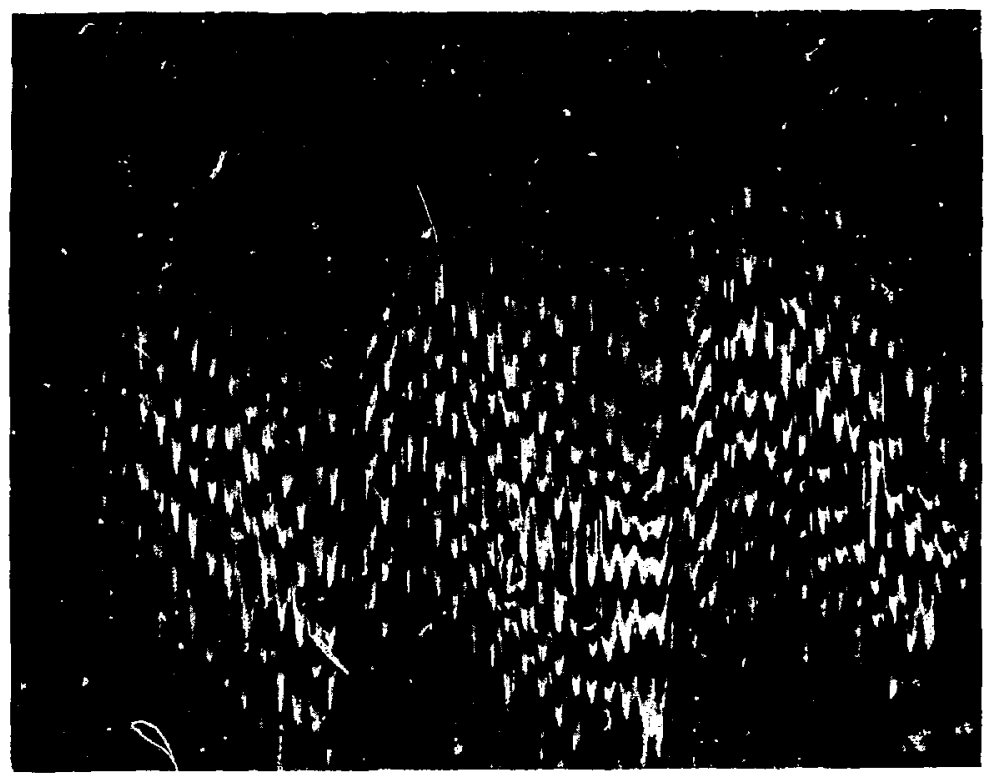

Fig. 5. Interference photomicrographs of Test Cut No. 2, (b) Finish 0.125 in. from end of cut, $337 \mathrm{x}$.

One attempt to reduce graphttization was to use a bonded polycrystalline diamond, anticlpartrig that the bonding agent would enhance heat conductivity and consequently keep the tool temperalure lower. A Megadlamond tool (\#2-A) was held in the negative rake tool holder, spindle speed was set to approximately 100 $\mathrm{Ipm}$, and feed rere was $0.130 \mathrm{in.} / \mathrm{min}$ (3.302 mm/min) with a depth of cut of $0.001 \mathrm{1m}$. $(0.0254 \mathrm{~mm})$. Freon TF was used as a cutting fluid. The nose radius was small on this tool, approximately $0.007 \mathrm{in} .(0.1778 \mathrm{~mm})$. Because of the poor radius of the unlapped tool and the resulting poor surface flntsh, an effort was made to obtaln polycrystalline diamonds with a lapped face. Several spectmens were provided for the experiment by Megadiamond Corporation. 


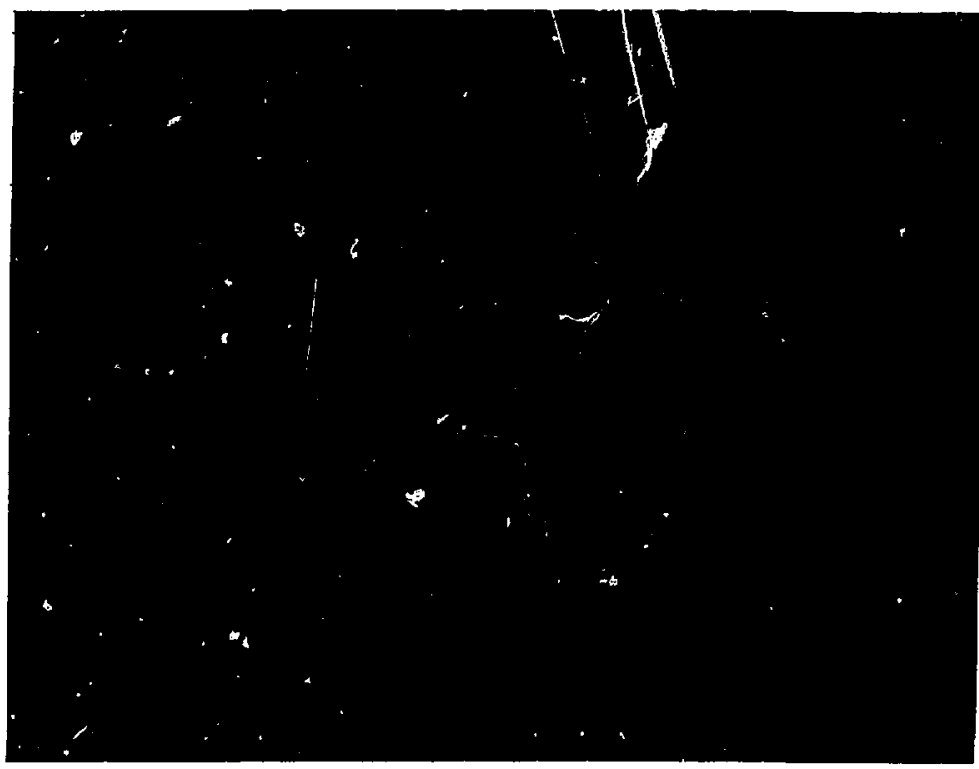

Fig. 6. Moore diamond tool \#L-42. (a) Top view, $121 x$.

A comparison of the results of the facing cuts is given in Table D-1 in Appendix D.

LONGITIMINAL TURNING CUTS - WEAR TESTS

\section{Following the recelpt of the}

lapped Megadiamond Inserts, we made a series of longitudinal turning cuts at constant surface speed to ascertain the tool wear rate at various cutting speeds. These tools had a 0.015-1n. (0.381-mm) nose radius and consequently required smaller feed rates than those for the single-crystal dlamond tools to achleve the same theoretical surface finish. The coolant used was Freon TF. Cutting conditions were standardized at a depth of cut of $0.001 \mathrm{in}$. (0.0254 mm), and feed rate was set at $0.105 \mathrm{in} . /$ $\mathrm{m} 1 \mathrm{n}(2.667 \mathrm{~mm} / \mathrm{min})$. 


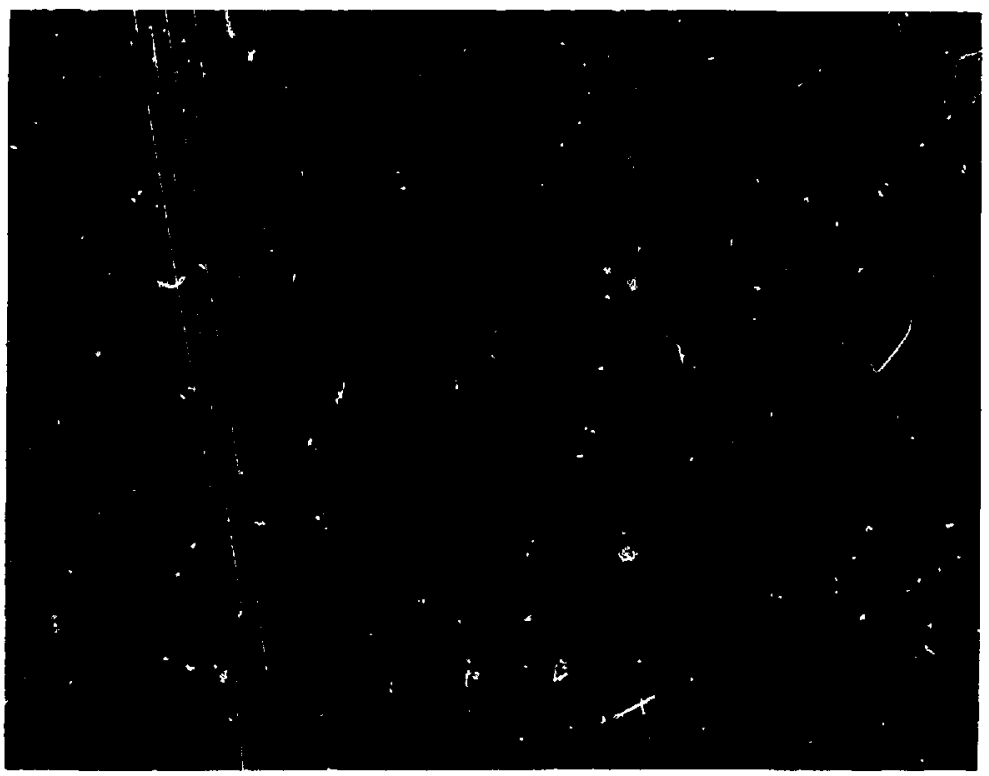

Fig. 6. Moore diamond tool th-42, (b) Front view showing flank wear, $337 \mathrm{X}$.

Flank wear was measured using a Bausch and Lamb Stereozoom Mifroscope with a $20 x$ eyeplece and 0.7 to $3.0 \mathrm{x}$ zoom lens. An eyepiece reticle was used for measuring flank wear. A stopwatch was used for accurately measuring cutting time, and tests were run at total lapoed times of 10 ,
$20,50,100,200$, and $500 \mathrm{~s}$. Data from these tests were plotted and are shown in Figs. 13 through 20 . A $\log / \log$ plot far the tool-1ife curve of diamond tool wear is shown In F1g. 20. This plot shows that diamond tool life follows the general Taylor Relat lonship. 


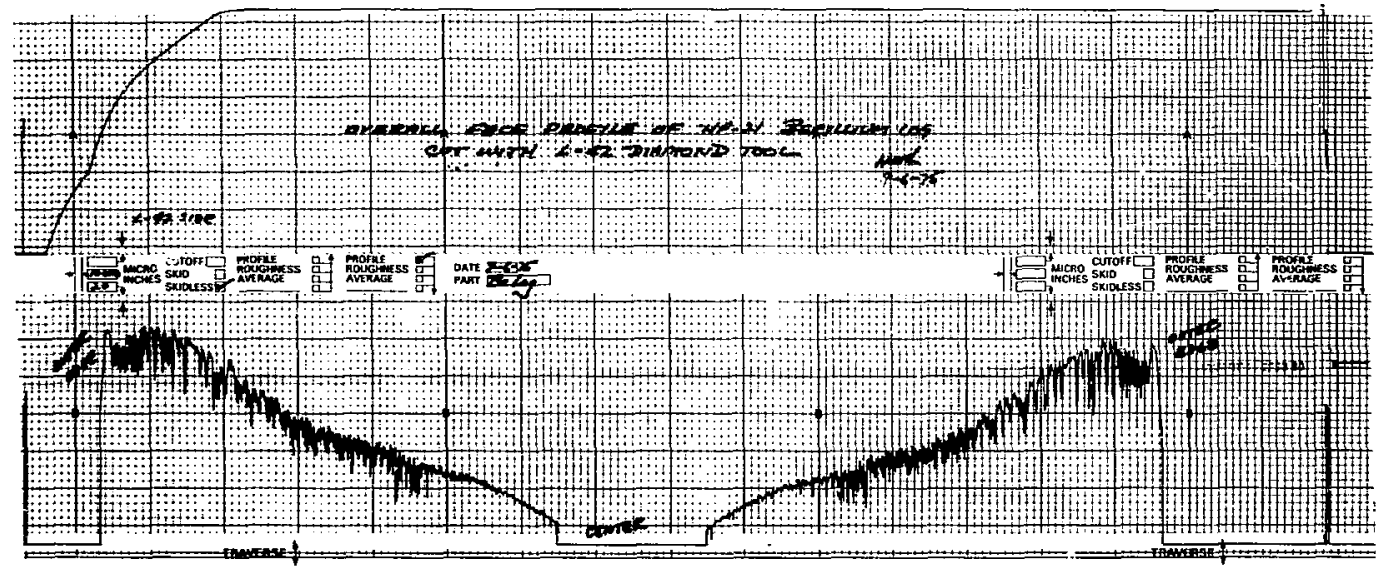

F1g. 7. Trace of face cut with tool L-42: no coolant. 


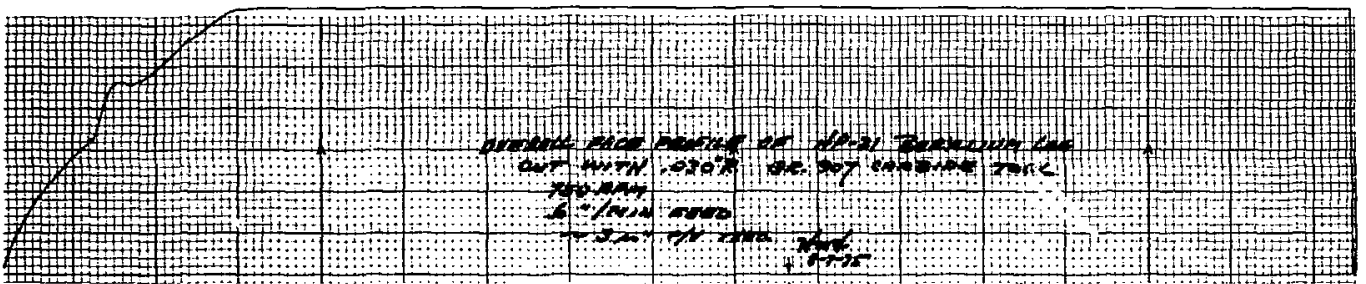

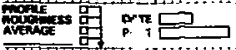

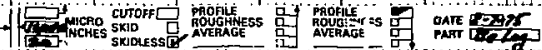
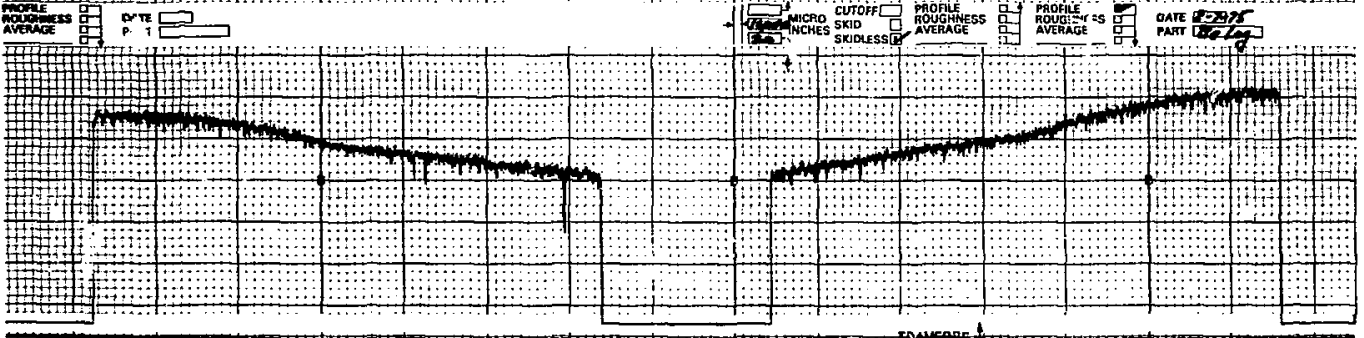

Fig. 8. Trace of face cut with 907 grade carbide: no coolant. 


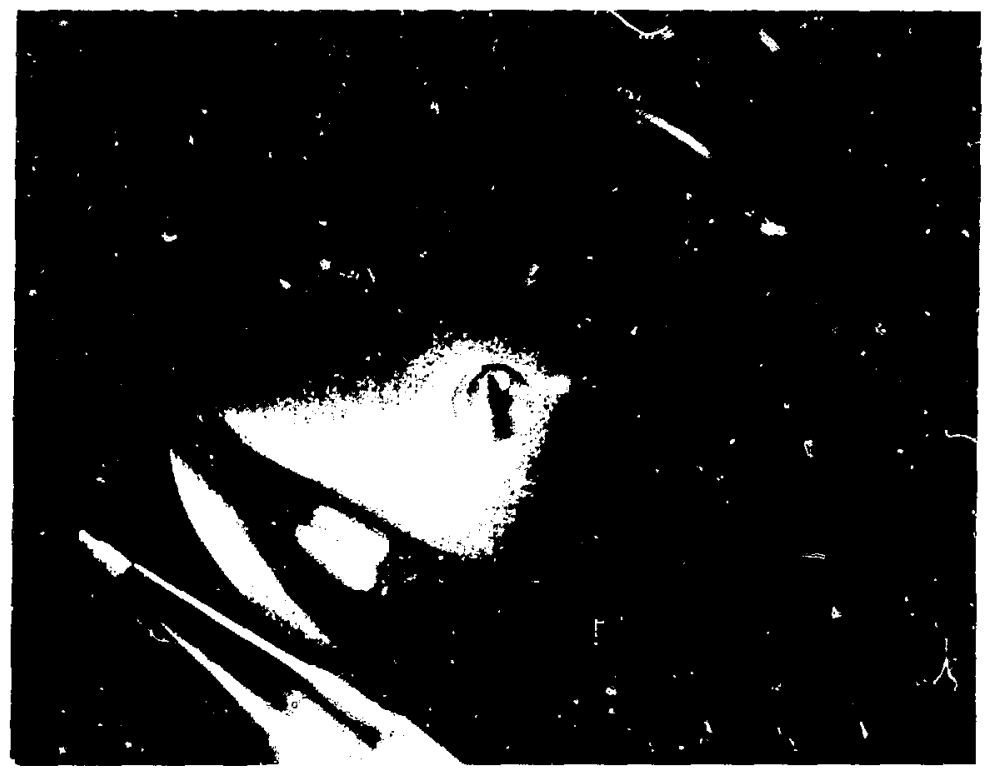

F1g. 9. Surface photographs. (a) Diamond turned with Noore tool 3 E-4, 3X. Pencil shows reflectivity. 


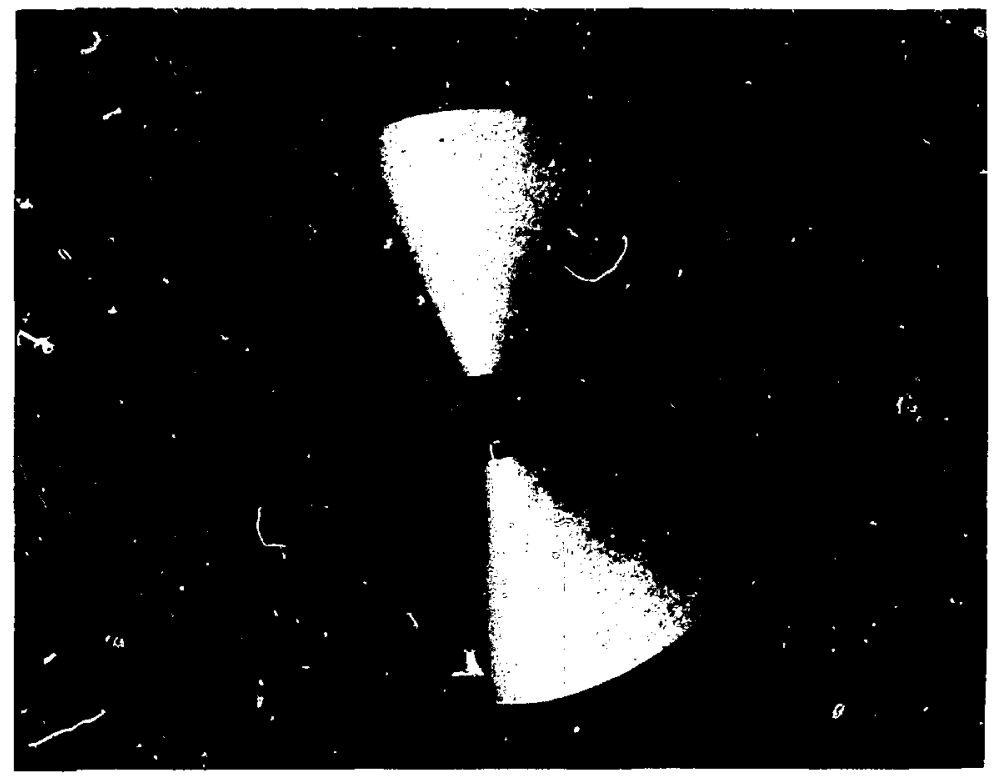

Fig. 9. Surface photographs. (b) Cut with 907 grade carbide too1, 3X. 


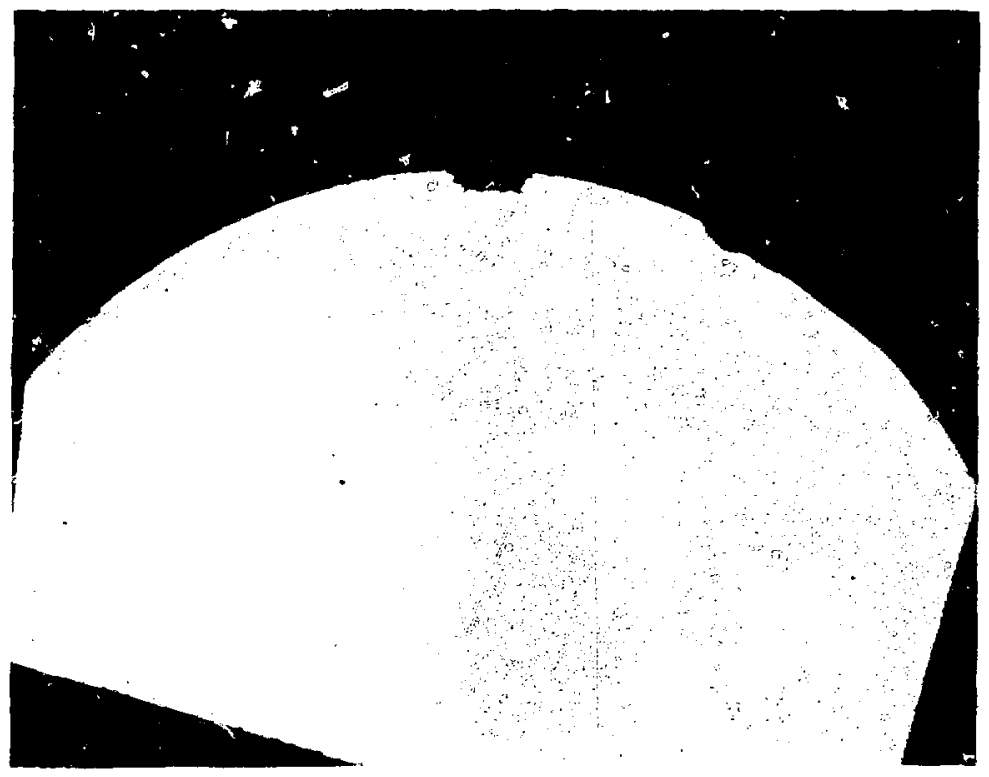

Fig. 10. Moore diamond tool $\forall E-4$. (a) Top view, 121X. 


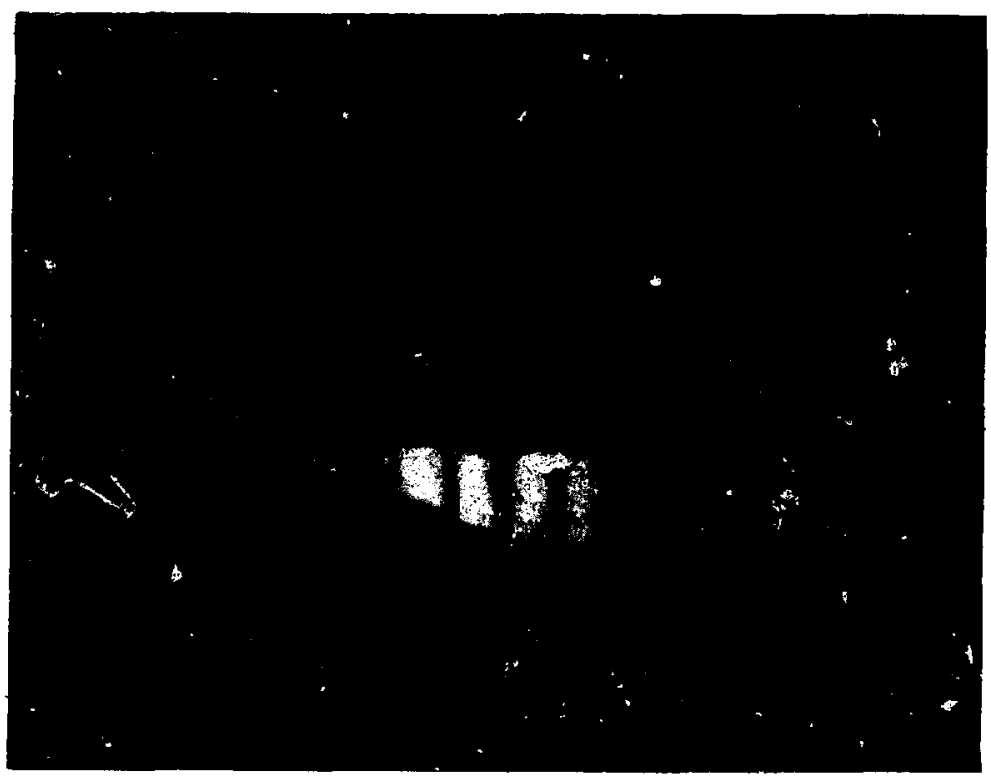

Fig. 10. Moore diamond tool \#E-4. (b) Front view showing flank wear, $337 \mathrm{X}$. 


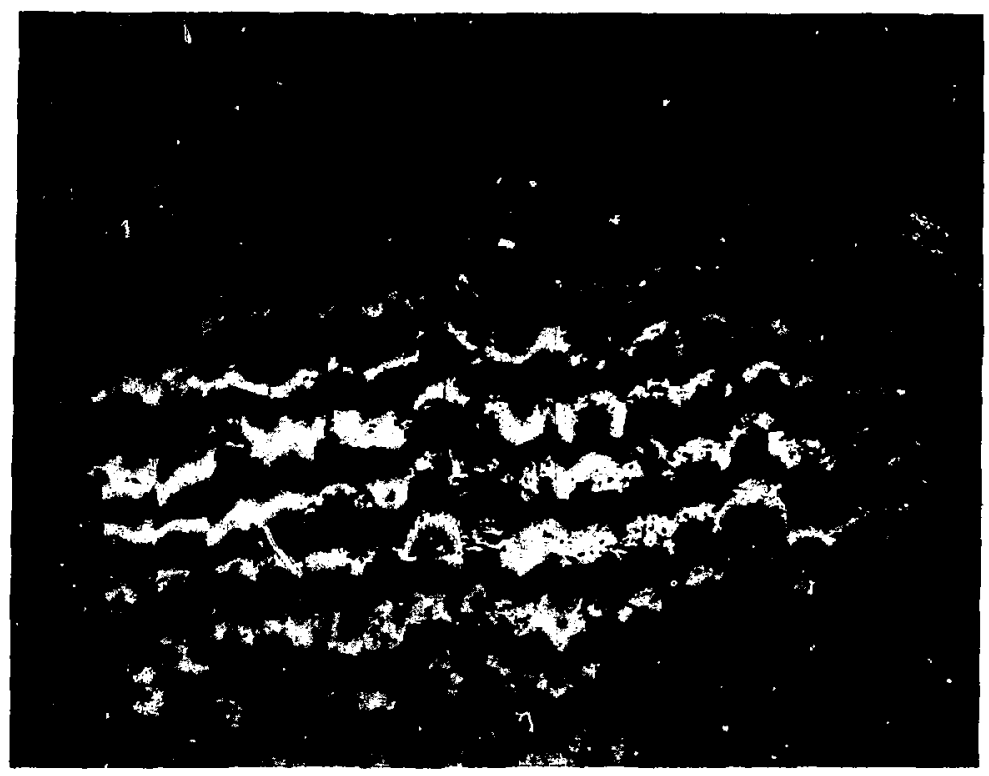

Fig. 11. Interference photomicrographs of Test cut No. 5. (a) Finish at start of cut, $337 \mathrm{X}$. 


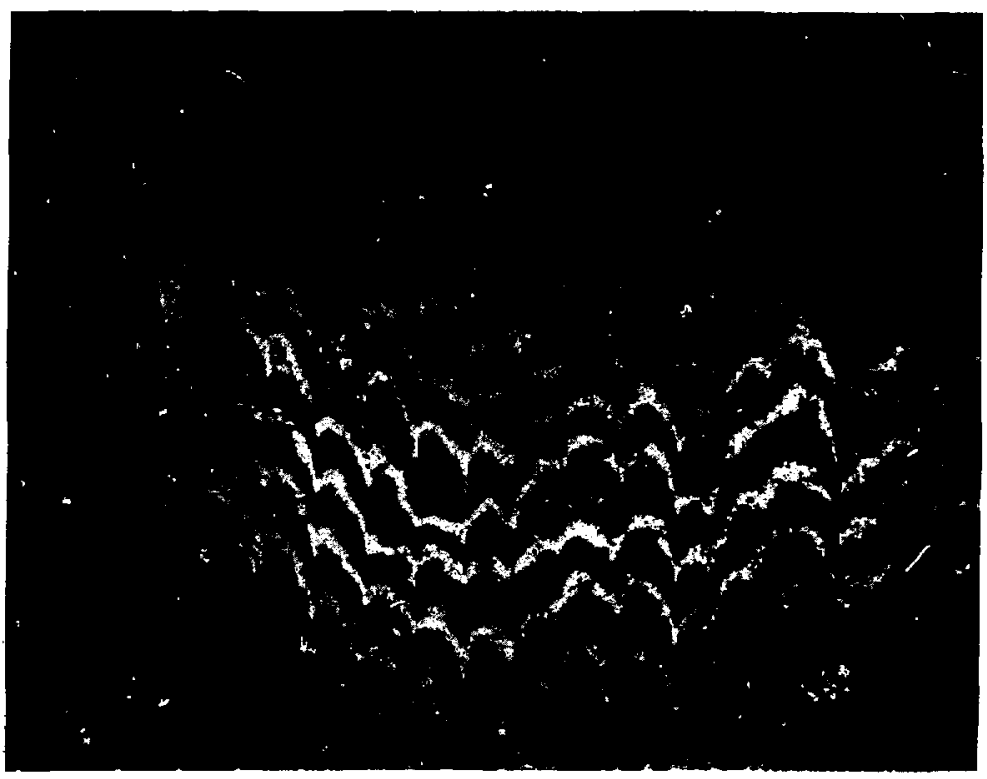

F1g. 11. Interference photomicrographs of Test Cut No. 5. (b) Finish at end of cut, 337x. 


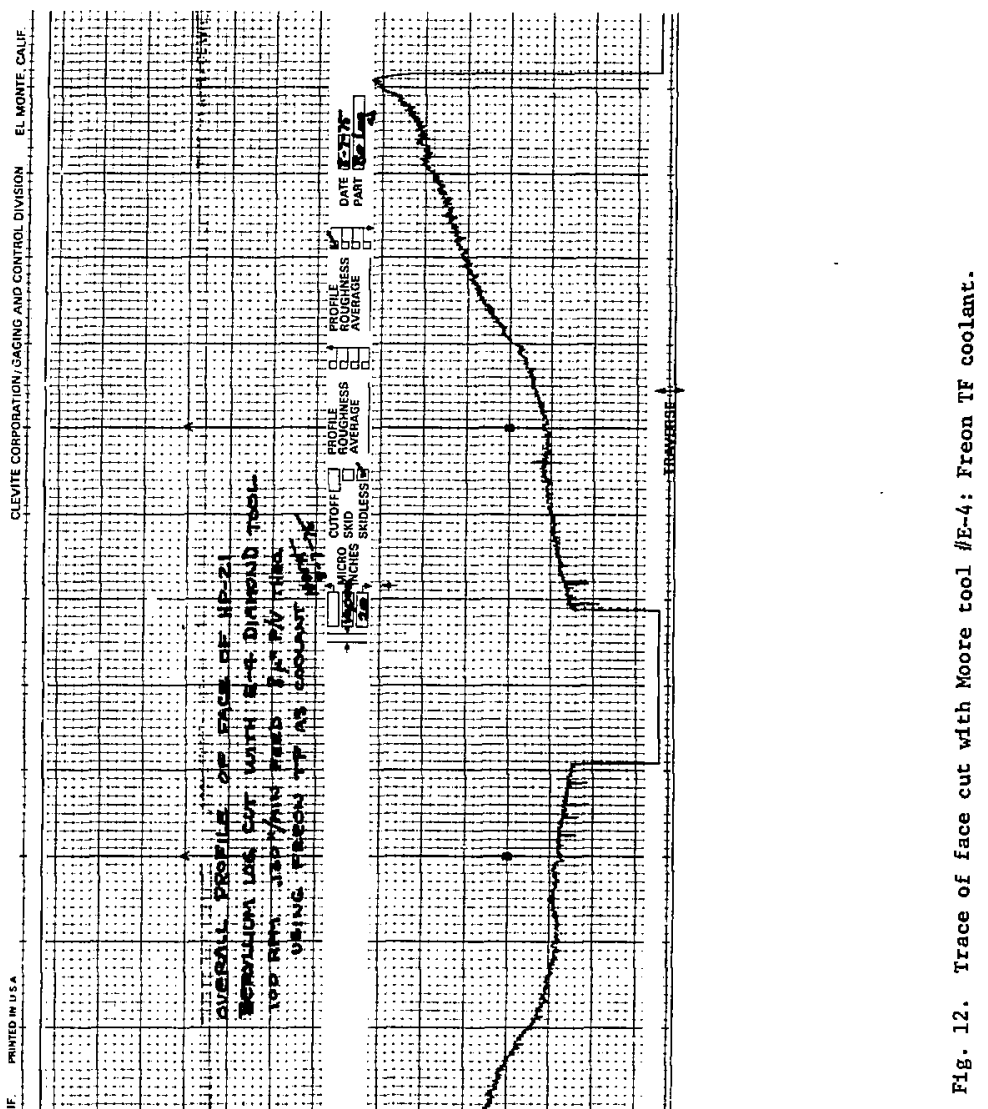




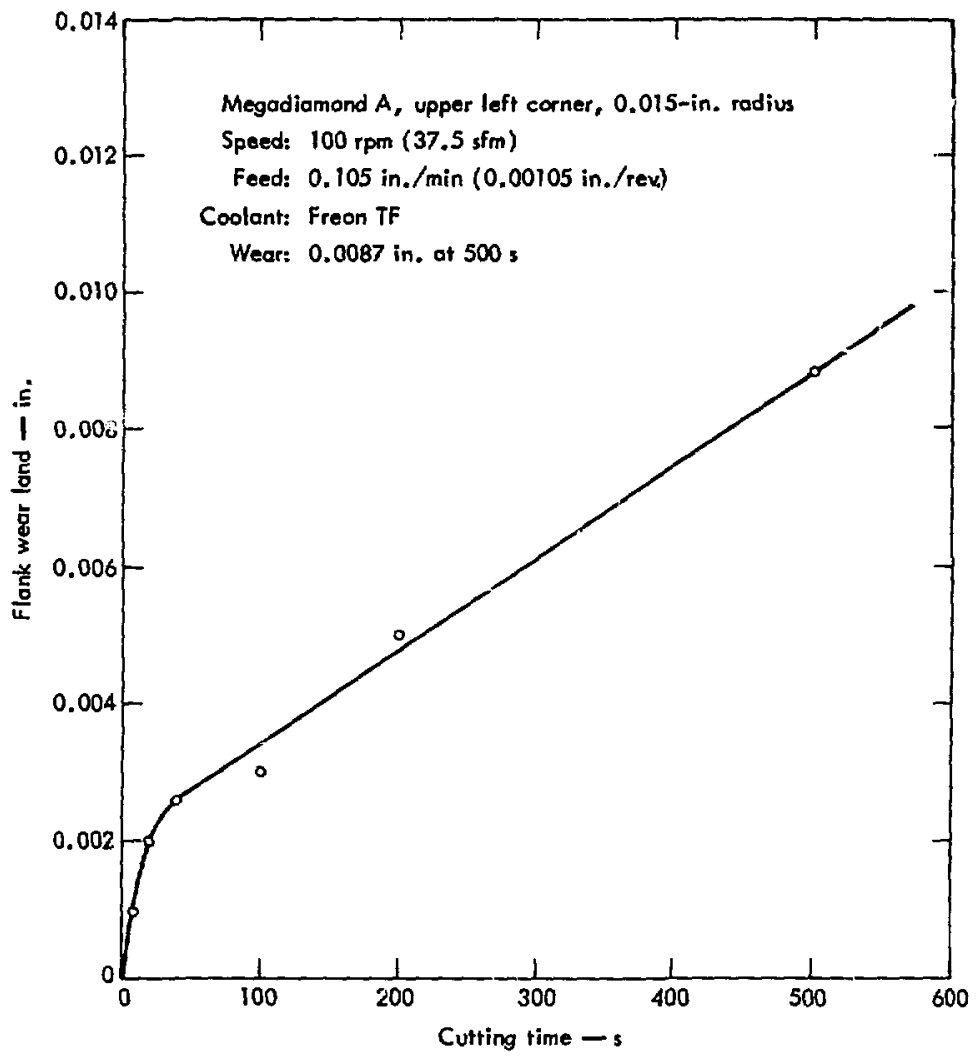

F1g. 13. Plot of tool wear for Megadiamond A, Wear Tes: No. 1. 


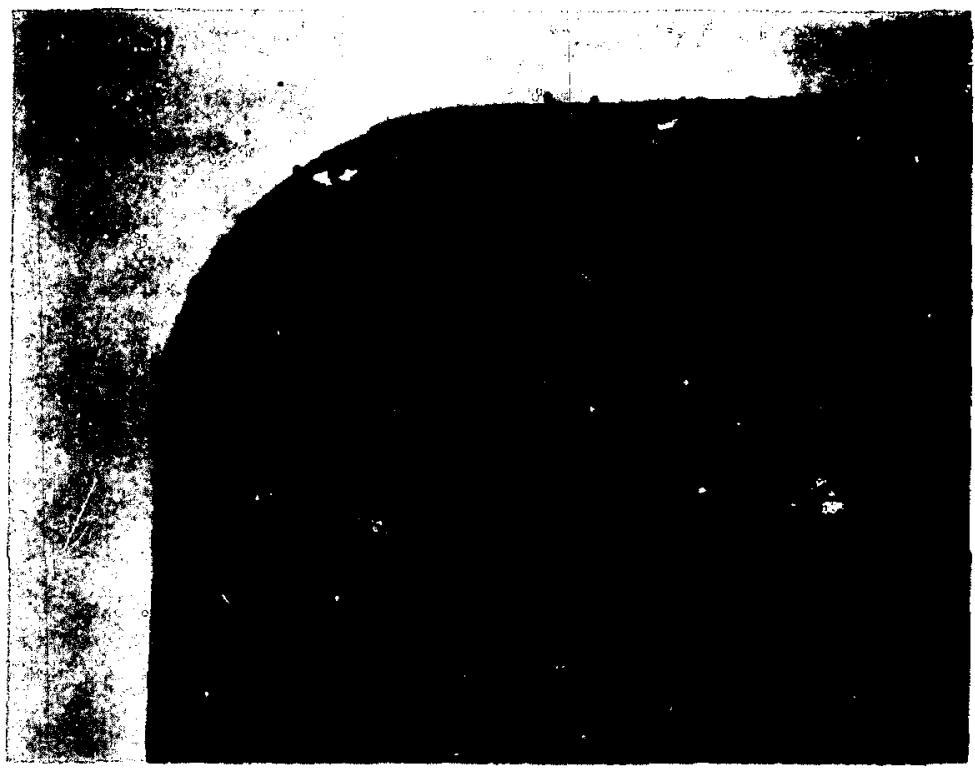

F18. 14. Megadiamond A after liear Test so. 1. (a) Top vien, 121x. 


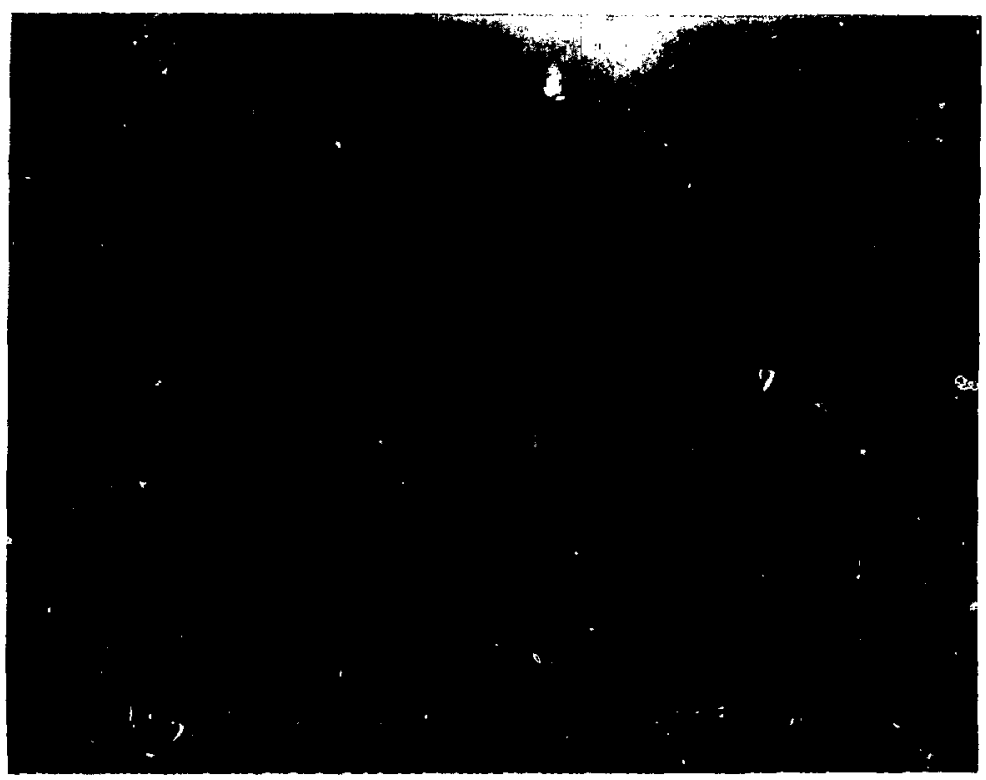

Fig. 14. Megadiamond $A$ after Wear Test No. 1.

(b) Front vlew showing flank wear, $121 \mathrm{X}$. 


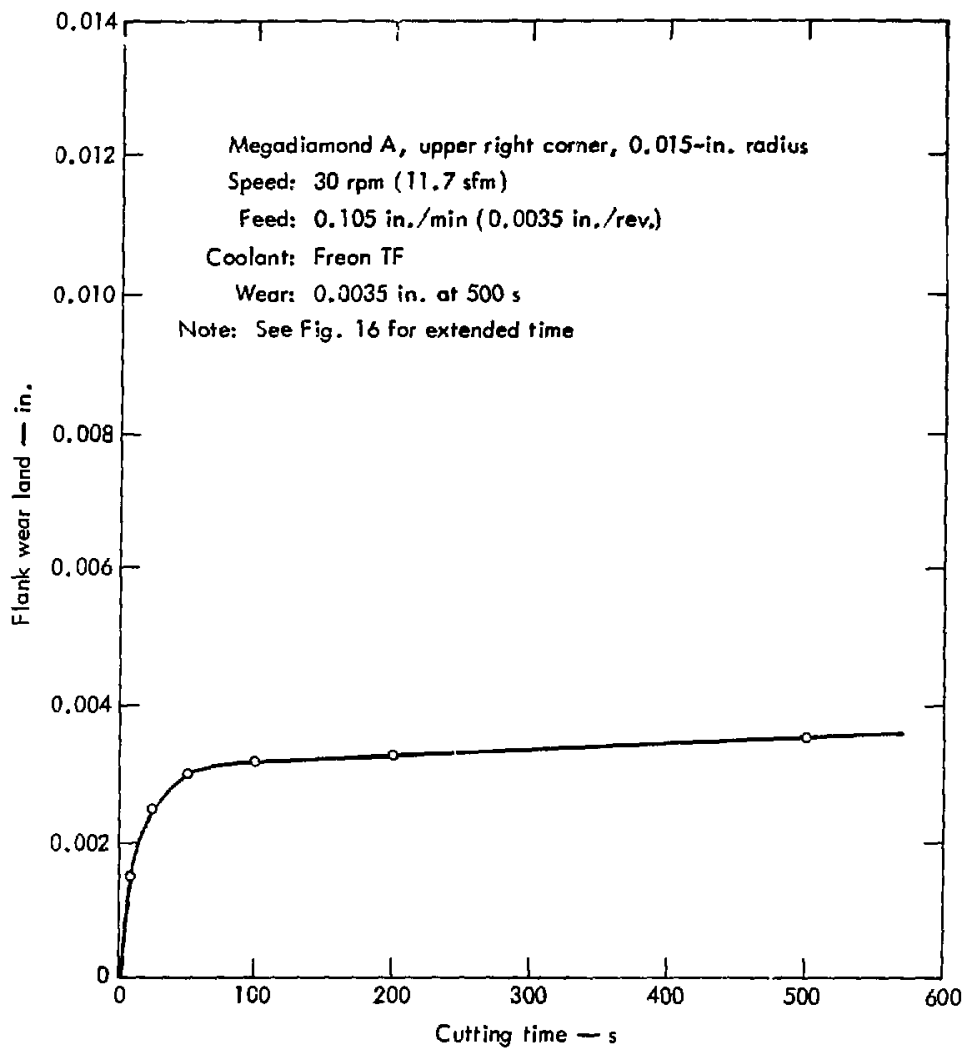

Fig. 15. Plot of tool wear for Megadiamond A, Hear Test No. 2. 


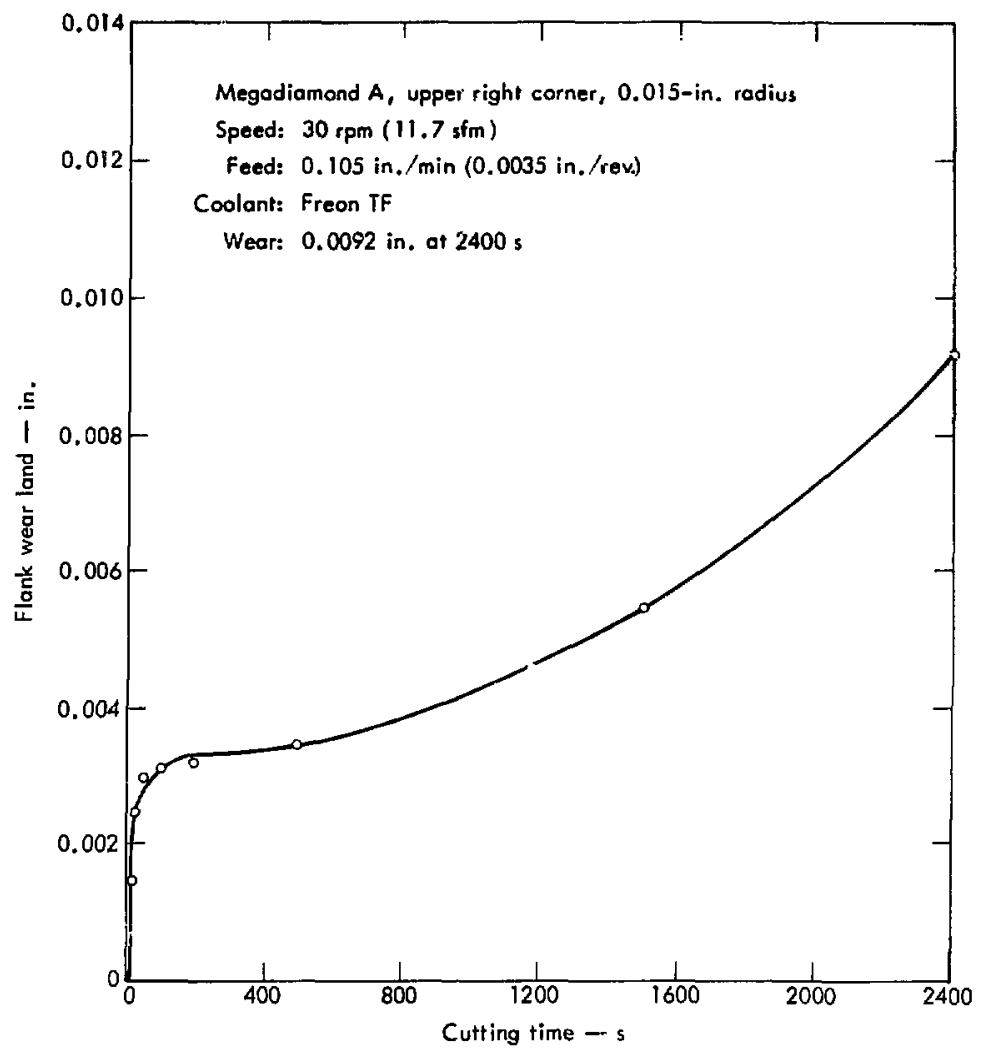

F1g. 16. Plot of extended-time tool wear for Megaulamond A, Wear Test No. 2. 


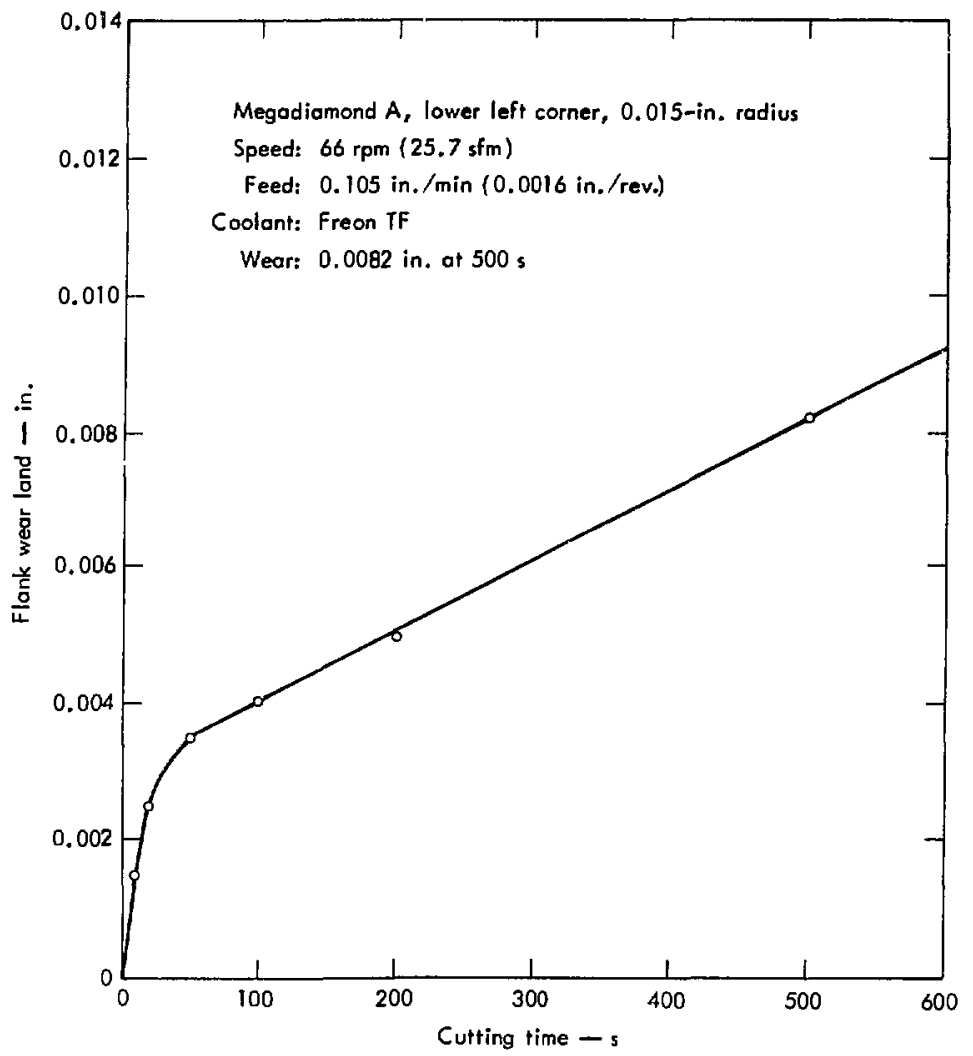

F1g. 17. Plot of tool wear for Megadiamond A, Wear Test No. 3. 


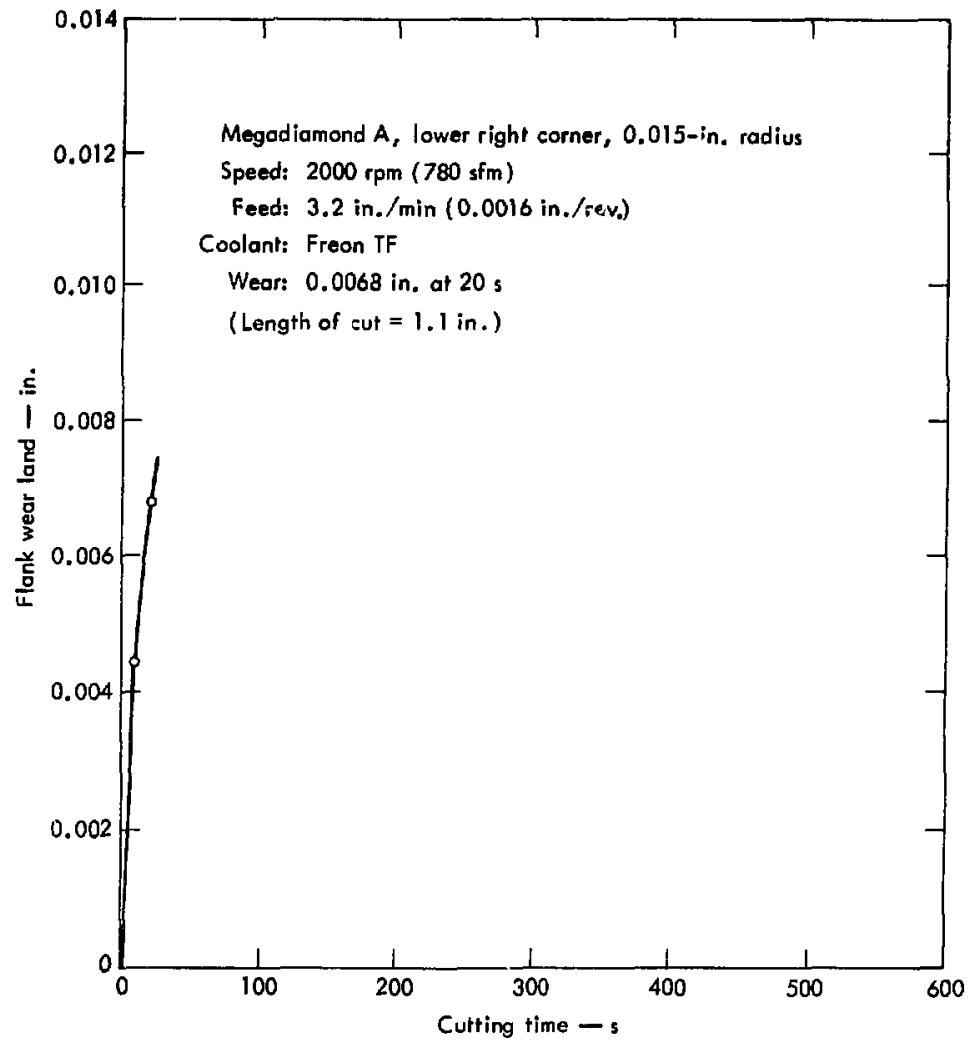

F13. 18. Plot of tool wear for Megndlamond A, Wear Test No. 4. 


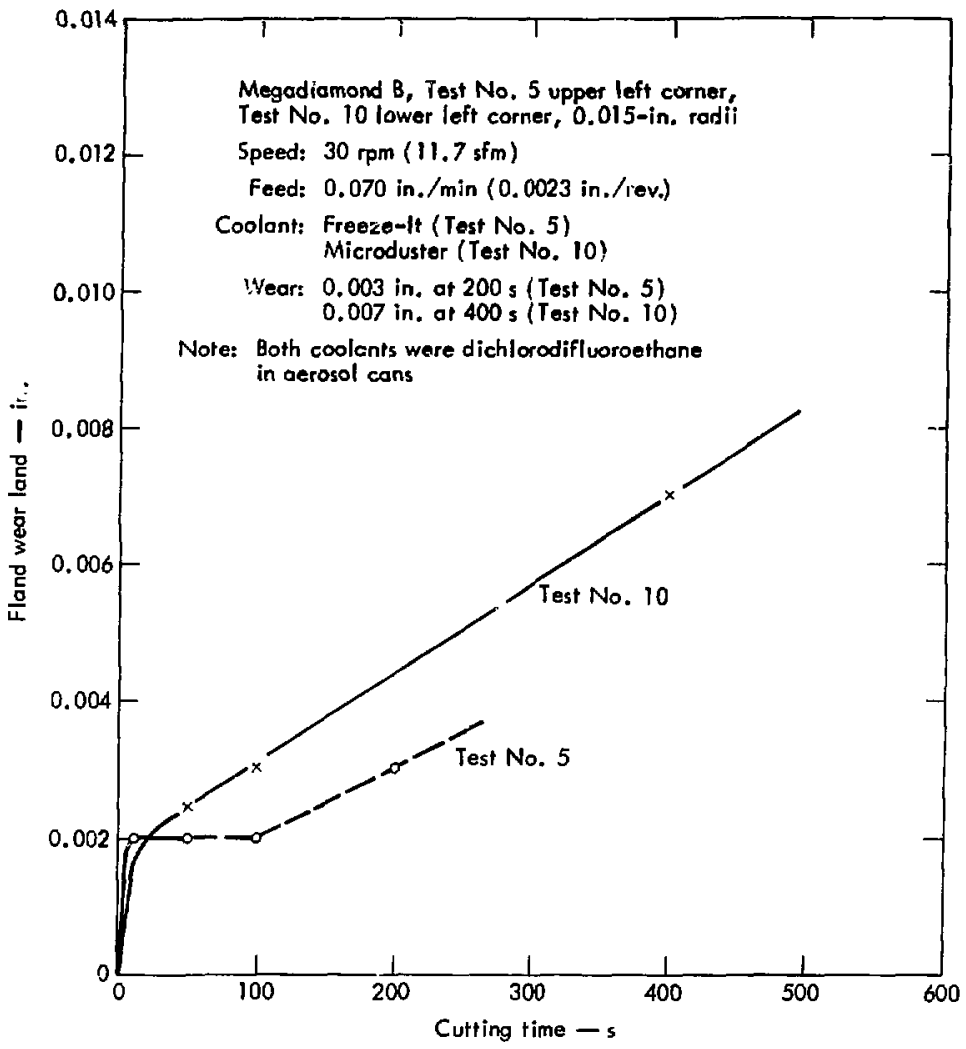

F1g. 19. Plot of tool wear for Megadiamond B, Wear Teet Nos. 5 anc 10. 


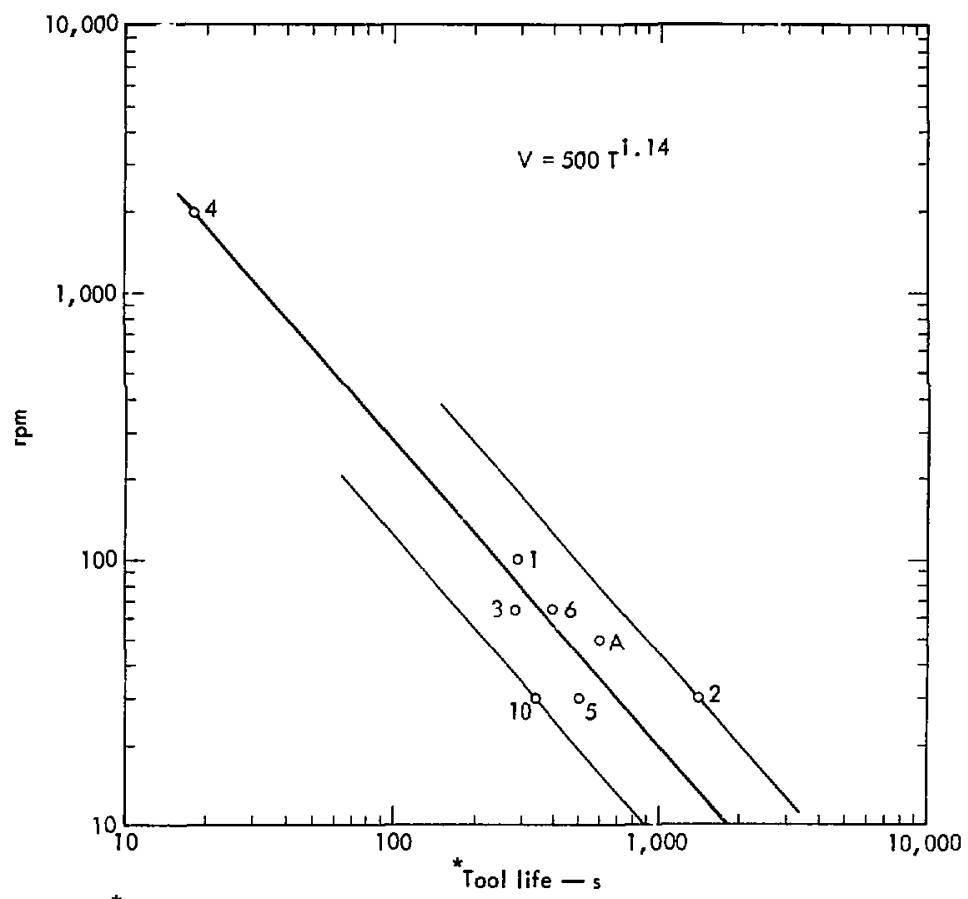

*Based on 0.006 in. flank wear land

51g. 20. Too1-life plot, $\log / \log$, Wear Test Nos, $1,2,3,4,5,6,10$, and $A$. 
Wear Test No. 1

Wear Test No. 1 was a cylindrical cut on a beryllium log. The tool used was Megadiamond $A$, upper left corner, with a nose radius of 0.015 1n. $(0.381 \mathrm{~mm})$. The cutting speed was $100 \mathrm{rpm}$, equivalent to 39 surface t $t / \mathrm{min}$. The feed rate was $0.105 \mathrm{in.l}$ $\mathrm{m} 1 \mathrm{n}(2.667 \mathrm{~mm} / \mathrm{m} 1 \mathrm{n})$, and the coolant used was Freon TF.

The total length of time on this cut was $500 \mathrm{~s}$, with the tool removed and inspected for wear at total lapsed times of $10,20,50,100,200$, and $500 \mathrm{~s}$. The total wear was $0.0087 \mathrm{in}$. $(0.2210 \mathrm{~mm})$. The data taken from the different test times are plotted in F1g. 13, and the tool used is shown in Figs. 14a and $14 \mathrm{~b}$.

Wear Test No. 2

Wear Test No. 2 was also a cylindrical cut using Megadiamand A, upper right corner. The cutting speed was $30 \mathrm{rpm}$, and the feed rate was $0.105 \mathrm{in} . / \mathrm{min}(2.667 \mathrm{~mm} / \mathrm{min})$. The coolant used was Freon TF.

The slower sreed allowed us to cut for a considarably longer pertod of time, and the data taken were extended through a time period of $2400 \mathrm{~s}$. At the end of the 2400-s cutting perlod, the tool wear measured $0.009 \mathrm{in}$. $(0.2338 \mathrm{~mm})$. The data from this cut are plotted in F1gs, 15 and 16. Figure 16 shows wear beyond the 500-s time period.

\section{Wear Test No. 3}

Wear Test lio. 3 was a cylindrical cut using regadiamond A, lower left corner. The cutting speed for this test was $66 \mathrm{rpm}$, equivalent to 25 surface $\mathrm{ft} / \mathrm{min}(7.62 \mathrm{~m} / \mathrm{min})$. The feed rate was $0.100 \mathrm{in.} / \mathrm{min}(2.54 \mathrm{~mm} /$ min), and the coolanc used was Freon TF. The duration of cut was a total of $500 \mathrm{~s}$, and tool wear at the end of this time was $0.0082 \mathrm{1n} .(0.2083 \mathrm{~mm})$. Data for this test are plotted in Fig. 17.

\section{Wear Test No. 4}

Wear Test No. 4 was conducted with Megadlamond A, lower right corner, at a speed of $2000 \mathrm{rpm}$ in an effort to :ielp ascertaln the effect of high texperature on graphitization. Freon TF was us'ed as a cutting fluid, and the cut was run for $20 \mathrm{~s}$, after which the flank wear was found to be 0.0068 in. (0.1727 mins). Th1s provided an additional point on the tool-life crurve and was found to ift well into the previous data (Fig. 18). 
Wear Test No. 5

Wear Test No. 5 was conducted using Magadiamond B, upper left corner, at $30 \mathrm{rpm}$ and a feed rate of $0.070 \mathrm{1n.} / \mathrm{min}(1.778 \mathrm{~mm} / \mathrm{min})$. "Freeze-It" cutting fluid, supplied by Aervoe Products, was used in this test. The Freeze-It solution was sprayed over the tool to reduce tis temperature to $-50^{\circ} \mathrm{F}\left(-46^{\circ} \mathrm{C}\right)$.

We observed a very low wear rate on the polycrystalline diamond during the $200 \mathrm{~s}$ it was used in the test. Fle ak wear 1 and was $0.0028 \mathrm{in}$. $(0.0711$ am) (Fig. 19). A repeat of this test using "Mlcroduster," another Freon spray, for a longer time period is also shown in Fig. 19 for comparison.

\section{Near Test No. A}

Wear Test No. A was intrially a cleanup cut. for the workplece, but was timed at $21 \mathrm{~min}$; the flank wear after 2 J. $\mathrm{min}$ was $0.0103 \mathrm{1n}$. (0.2616 man). This test also provided an additional point on the tool-life surve (FIg. 20).

\section{Wear Test No. 6}

Wear Test No. 6 was a bestfinish effort with polycrystalline diamond. The cutting speed was 66 rpm with a cutting time of $400 \mathrm{~s}$.
Freon TF was used as the cutting fluid. The theoret'cal surface finish was $14 \mu \mathrm{in}$. $(0.35 \mu) \mathrm{P} / \mathrm{V}$. The actual surface finish achieved was in the range 25 to $80 \mu \mathrm{in}$. (0.635 to $1.65 \mu$ ) $P / V$. This was an unsatisfactory finish and may be partially attributed to the poor fintsh on the tool nose.

\section{Wear Test No. 7}

Wear Test No. 7 was the same as test No. 6 , but we used a singlecrystal diamond, Moore tool $t \mathrm{E}-3$. Cutting conditions were the same except that the depth of cut was $0.00075 \mathrm{1n}$. (0.0191 mm) instead of 0.001 in. $(0.0254 \mathrm{~mm})$. The surface fintsh was measured in the range 15 to $100 \mu i n$. $(0.381$ to $2.54 \mu) \mathrm{P} / \mathrm{V}$ as compared to 25 to $80 \mu i n$. (0.635 to $1.65 \mu)$ for the polycrystalline diamond. During the Initial phases of the test, the single-crystal diamond produced a much better surface than did the polycrystalline diamond, but the single-crystal-diamond finish deterforated more rapidly.

\section{Wear Test No. 8}

In Wear Test No. 8 a factng cut was made to determine $f f$, using the information we gathered on cutting speeds and flufds, a surface finish 
of optfcal quality could be obtained. lloore singie-crystal-d Lamond tool fIE-3 was used, For this test the cutting speed was $66 \mathrm{rpm}$, and the feed rate was $0.024 \mathrm{in.} / \mathrm{min}$ (0.6096 $\mathrm{mn} / \mathrm{mfn}$ ). This should have given us a theoretical finish of $0.5 \mu \mathrm{fn}$. $(0.0127$ 1) $\mathrm{P} / \mathrm{V}$. The coolant used was Freon TF.

Because of the exceedingly slow feed rate and because wear is a factor of time, the tool wore to the point where tool pressure was finally high enough to break $1 t$. This occurred at approximately $17.5 \mathrm{~min}$ in cutting time. The finish was then evaluated and charts made.

It is interesting to note that although the theoretical fintsh was set at $0.5 \mu \mathrm{in} .(0.01 \geqslant 7 \mu)$, the actual flnish was not that good on the plece, partly because of the machine capabllity; the findsh was apparently no better than would have previously been achieved with a coarser feed rate. For this reason all subsequent machining on beryllium was done at about a 0.001-1n./rev. (0.0254-ton/ rev.) feed rate.

\section{Wear Test No. 9}

Wear Test No. 9 was not documented because of the problem encountered with the diamond tool breaking in the previlous cut. It is noteworthy that here an attempt was made to use liquid nitrogen as a coolant to further lower cutting temperatures. We found it very difficult to cool sufficlently usting liquld nftrogen, because unless the material to be cut were at the ambient temperature of the liquid nitrogen, the coolant would tend to splatter off the surface and not effectively cool at all. fnother problem was in trying to maintain a steady flow of liquid nltrogen. Freeze-It aerosol spray was far more effective in cooling the bar quickly.

\section{Wear Test No. 10}

In Wear Test No. 10 a cylindrical cut was taken at $30 \mathrm{rpm}$ and a feed rate of $0.070 \mathrm{In.} / \mathrm{m}(1.778 \mathrm{~mm} / \mathrm{mIn})$ with a cutting depth of 0.001 in. (0.0254 mm) using Microduster. By inverting the can, the freezing application that we had obtained previously with Freeze-It was duplicated.

The purpose of this test was to extend what had been done in Test No. 5 to a cotal time of $400 \mathrm{~s}$ to help plot the previous cest and determine what the wear rate really would be Th1s was done, and there was flank wear of $0.007 \mathrm{in}$. $(0.1778 \mathrm{~mm})$ at the end of $400 \mathrm{~s}$ cutting time. This 
ccrrelated we11 with the information obtained earlier (Fig. 19).

Wear Test No. 11

Wear Test No. 11 was a cylindrical cut using a carbide grade 907 tool at $400 \mathrm{rpm}$ with a 1.1-1n./min (27.94$\mathrm{mm} / \mathrm{min}$ ) feed rate, and a $0.001-1 \Omega$. (0.0254-mm) depth of cut. This was cut dry and was merely a cleanup cut, but it was timed and the flank -iar on the tool was checked. The length of the cut was approximately $1.5 \mathrm{in.}(38.1 \mathrm{~mm})$. The cutting time was $95 \mathrm{~s}$. Flank wear was measured at $0.002 \mathrm{in.}(0.0508 \mathrm{~mm})$, considerably less than expected with a dianond tool.

\section{Wear Test No. 12}

Wear Test No. 12 was a facing cut using a 907 grade carbide tool with a $0.130-1 \mathrm{n} .(0.762-\mathrm{nm})$ nose radius. The cuiting speed was 100 rpm, and the feed rate was $0.130 \mathrm{in.l}$ $\mathrm{min}(3.302 \mathrm{~mm} / \mathrm{min})$. The depth of cut was $0.001 \mathrm{fn}$. $(0.0254 \mathrm{~mm})$, and the cutting fluid was perchloroethylene, commonly called "perk."

The object of this test was to determine whether or not perk was a better cutting fluid than Freon TF.
Tool flank wear was measured on this test at $0.003 \mathrm{in.}(0.0762 \mathrm{~mm})$. Because of the slow feed rate and speed the tool falled at a diameter of approximately $0.61 \mathrm{n}$. (15.24 III)). The reason for this cut at this speed and feed was to compare the carbide tool to the diamond tool at the same cutting parameters described in Wear Test No. 13.

\section{Wear Test No. 13}

Wear Test No. 13 was a facing cut also using perk as a cutting fluid. We used a Moore diamond tool th-44 located on a fresh tool edge. The cutting speed was $100 \mathrm{rpm}$, the feed rate 0.130 in./min (3.302 $\mathrm{mm} / \mathrm{min})$, and the depth of cut 0.001 in. $(0.0254 \mathrm{~mm})$. The flank wear was neasured at $0.0059 \mathrm{ln}$. $(0.1499 \mathrm{~mm})$.

The finish on the plece was not as good as that obtained with Freon TF. This plece was parted off the end of the $\log$ as a disk $0.25 \mathrm{in}$. $(6.35 \mathrm{~mm})$ thlck and $1.5 \mathrm{in.} \mathrm{(38.1} \mathrm{mm)}$ In diameter. This disk was then studied under the scanning electron microscope, and a microanalysts of the material was performed.

A compartson of the results of the wear tests is given in Table $\mathrm{D}-2$ in Appendix D. 
FACING CUTS ON DISK SPECLMENS

To document mare completely the attempts to achieve an optical fintsh on beryllium usting dlamond tools, we declied to supply the recilestor of this report with samples of the actual turned surfaces. This was accomplished using a carbide parting tool to part off disks approxlmately 0.25 in. $(6.35 \mathrm{~mm})$ thick and $1.5 \mathrm{in}$.

$(38.1 \mathrm{~mm})$ in diameter. The disks were held in the aluminum soft-jaw collet in the Hardinge spindle (FIg. 2). This factlitated the easy removal and replacement of disks to maintain parallelism and allowed us to take a series of facing cuts when necessary.

In the process of cutting these disks, two trial cuts were made using ceramic tools. These cuts proved that the ceramic tool not only wore to the extent of diamond tools, but produced an unacceptable fintsh in terms of optical quality. The data recelved from these tests can be seen in Table D-3 (Appendix D), but w111 not be included in the sample disks provided.

Disk A

Disk A was a brass disk face cut to show the maximum machining capabllity of the Hardinge Lathe on a materlal that can be diamond turned to optical surfaces. Because brass can be readily diamond machined to optical quality surfaces, it was selected to give a reference as to what the machine could produce. Disk $A$ was placed in the collet, faced with a preliminary facing cut wth a carblde tool, and Moore diamond tool \#L-23 was inserted Into the Aloris holder. The spindle speed for this cut was 400 Ipm, the feed rate was $0.130 \mathrm{fn} . / \mathrm{min}(3.302 \mathrm{~mm} / \mathrm{min})$, and a 0.001-in. (0.0254-min) depth of cut was taken. Kerosene was used as a cutting fluid.

The theoretical finish for which we set the machine spindle speed and feed rate was $0.5 \mu \mathrm{Hn} .(0.0127 \mu) \mathrm{P} / \mathrm{V}$. The disk was then checked on the clevite analyzer and found to have an actual surface finish of from 2 ro 5 Hin. $(0.0508$ to $0.127 \mu) P / V$, not including flaws in the materlal (volds and pits). This is the best finish that we achieved on the Hardinge Lathe.

\section{$\underline{D} 1 s \underline{k}$}

Disk B was also a brass disk used f or establishing a surface standard. The cutting parameters used were the same as those used for all the diamond turning of the beryl11um dist samples. The cutting speed was 100 
rpm, and the feed rate was $0.130 \mathrm{ln} . /$ $\mathrm{min}(3.302 \mathrm{~mm} / \mathrm{min})$. The theoretical finish of this feed rate and speed Is $7 \mathrm{\mu ln}$. $(0.1778 \mu) \mathrm{P} / \mathrm{V}$. The depth of cut was $0.001 \mathrm{in}$. $(0.0254 \mathrm{~mm})$, and again kerosene was used as the cutting fluid.

Moore diamond tool \#L-23 was again used; it had not been worn on the Disk A cur. Disk B was also checked with the clevite analyzer and had a surface finish of 5 to $8 \mu 1$. $(0.127$ to $0.203 \mu) \mathrm{P} / \mathrm{V}$, excluding material flaws. The overall finfsh proved to be very close to the

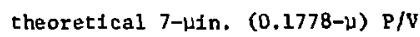
finish.

Disk C

Disk C was a HP-21 beryllium disk. It was cut with a 907 grade carbice tool and was included to show the surface to which all disks were cut prior to the diamond-turning cut described as a bastc surface. Disk $\mathrm{C}$ was provided to show the type of finish normally achieved on berylilum with standari manufacturing cechniques.' The cutting apeed was 460 $\mathrm{rpm}$, and the feed rate was $0.500 \mathrm{in./}$ $m a n(12.7 \mathrm{~mm} / \mathrm{min})$.

This should have created a 5$\mu \mathrm{in} .(0.127-\mu) \mathrm{P} / \mathrm{V}$ theorettcal finish. The carbide tool radius is the same as that of diamond tools, 1.e., a $0.030-1 \mathrm{n}$. (0.762-mm) radius. The beryllium was cut dry in this test. It is interesting to note that the flank wea from this cut on the carbide tool was $0.001 \mathrm{in}$. (0.0254 m), constderably less than that noted on diamond tools in the subsequent tests. The finish on Disk $C$ was checked on the clevite analyzer and found to be from 20 to $90 \mu \mathrm{In}$. (0.508 to $2.413 \mu) P / V$. The disk flatress was within 100 in. (0.00254 m) of the capability of this machine when compared to those cuts previously made on the brass disks. The concavity of the carbide-turned face did not result In a significant increase in depth of cut for subseguent dlamond-tool cuts.

\section{itsk D}

For the Disl: D test a dlamond tocil manufactured by Moore ("L-45) was used. This tool had a $0.030-1 n$. (0.762-mm) nose radius. The cutting speed was $100 \mathrm{rpm}$, and the feed rate was $0.130 \mathrm{ln} . / \mathrm{min}(3.302 \mathrm{~mm} / \mathrm{min})$. Th1s was intended to give a surface finish comparable to the brass Disk B, $7 \mu \mathrm{r}$. $(0.1778 \mathrm{~mm}) \mathrm{P} / \mathrm{V}$. The depth of cut was $0.001 \mathrm{in}$. $(0.0254 \mathrm{~mm})$, and Freon TF was used as a cutting fluld. By visual inspection we found a deterforation of finish with tool 
wear as it goes across the cut. The finish at the center of the disk measured $5 \mu \mathrm{in}$. $(0.127 \mu) \mathrm{P} / \mathrm{V}$ and compares well to the finish achleved on brass; howev:, as the tool

progressed across the piece and neared the end of the cut, the $P / V$ value $1 s$ $95 \mathrm{\mu ln}$. $(2.413 \mu)$, or approximately that achieved with carbide tools on this same materlal. The flank wear on the diamond tool measured 0.0047 1n. $(0.1194 \mathrm{~mm})$.

\section{$\underline{\text { Disk E }}$}

This cut on a beiyllium disk was made using a diamond tool from a different manufacturing source Citco Dtamond Tool Company. It was a single-crystal diamond with a $0.030-i n$. (0.762-mm) radius and was the same geometry as the tool used on Disk D. Orfentation of the diamond was not known.

The cutting parameters were also the sane as Disk $D$. The cut was made and the tool was inspected for wear. The flank wear measured $0.0059 \mathrm{in}$. (0.1499 mra). The disk was also $1 \mathrm{n}$ spected on the Clevite analyzer and found to have a finish of from 10 to $95 \mu \mathrm{in}$. (0.254 to $2.413 \mu) \mathrm{P} / \mathrm{V}$. Th1s tool did not give a fintsh as good as that of the Moore tool, and flank wear was slightly greater. Differences in these results $\mathrm{might}$ be explained by differences in diamond orlentstion. It is well known that diamond has sting directional properties.

\section{D1sk F}

The Disk F cut was made using a Megadiamond that had a lapped radius of $0.015 \mathrm{in} .(0.381 \mathrm{~mm})$. Because this radius is one-half that of the single-crystal diamonds, the theoretical finish was approximately

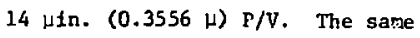
cutting parameters were used once more. The flant wear on the tool at the end of the cut was measured at $0.0076 \mathrm{in}$. $(0.1930 \mathrm{~mm})$.

This disk was also inspected on the clevite analyzer, and the surface profile was from 35 to $70 \mu 1 \mathrm{n}$. $(0.889$ to $1.778 \mu) \mathrm{I} / \mathrm{V}$. The finish was never as good as the theoretical finish, atiributed to the edge shape and smoothness of the Megadiamond insert. However, the tool did give a slightly better finish at the end of the cut than did the single-crystal diamonds. We belleve this occurs because as the tool wears, new diamond particles are constantiy being introduced that in effect give a sharper edge even though the tool has worn. Single-crystal diamond does not have this advantage. 
$\underline{\text { Disk G }}$

D1sk G was chemically milled 0.005 in. (0.127 mu) off each face to remove any surface Impurities possibly causing major tool wear. Because of uncertainty as to the depth that etching could remove impurities, a minimum depth cut was taker to clean the surface. The back side of the disk was faced using a diamond tool until parallel to the front. The plece was then turned in the collet, and the uncut face was checked for run out and found to be less than 0.0002 In. $(0.0051 \mathrm{~mm})$. A cut 0.0005 In. $(0.0127)$ deep was taken on the freshly etched surface.

Disk $G$ exemplifies the greatest success in achleving an optical surface with diamond turning. The finish values ranged from 5 to 35 $\mu$ in. $(0.127$ to $0.889 \mu) \mathrm{P} / \mathrm{V}$. This was perhaps the most encouraging information we had recelved to date. The flank wear on the Moore diamond tool \#E-5 was measured to be 0.0025 in. $(0.0635 \mathrm{~mm})$. Photomicrographs of the surface are shown In Figs. 21a and $21 \mathrm{~b}$.
Disk H

Disk H provided a comparison in machining a purer grade of beryllium. As can be seen in Appendix $C$, the history of analysis of this matertal showed it to have a purtty of $99.8 \%$ with very small amounts of beryllium oxide and other hard 1mpurtties. The disk was parted from a bar 2 in. $(50.8 \mathrm{~mm})$ In dtameter and approximately 12 1n. (304.8 $\mathrm{mm}$ ) 1ong. It was faced using carbide tools and drilled to relieve the center area. For this test the Moore diamond tool tE-5 used on Disk $G$ was again used by moving to a fresh portion of the tool. Prior to the finishing cut, a diamond roughing cut was made to remove any surface Impurities introduced by the carbide tool. A Moore. diamond tool /tL-23 was used with a 0.001-in. (0.0254-mm) depth of cut. This tool was measured to have 0.0024 1n. $(0.06096 \mathrm{~mm})$ flank wear. The surface of this disk was measured on the clevite analyzer and found to have from 10 to $90 \mu 1 n$. $(0.254$ to $2.286 \mu)$ $P / V$ and was not as reflective as the chemically milled HP-21 disk. 


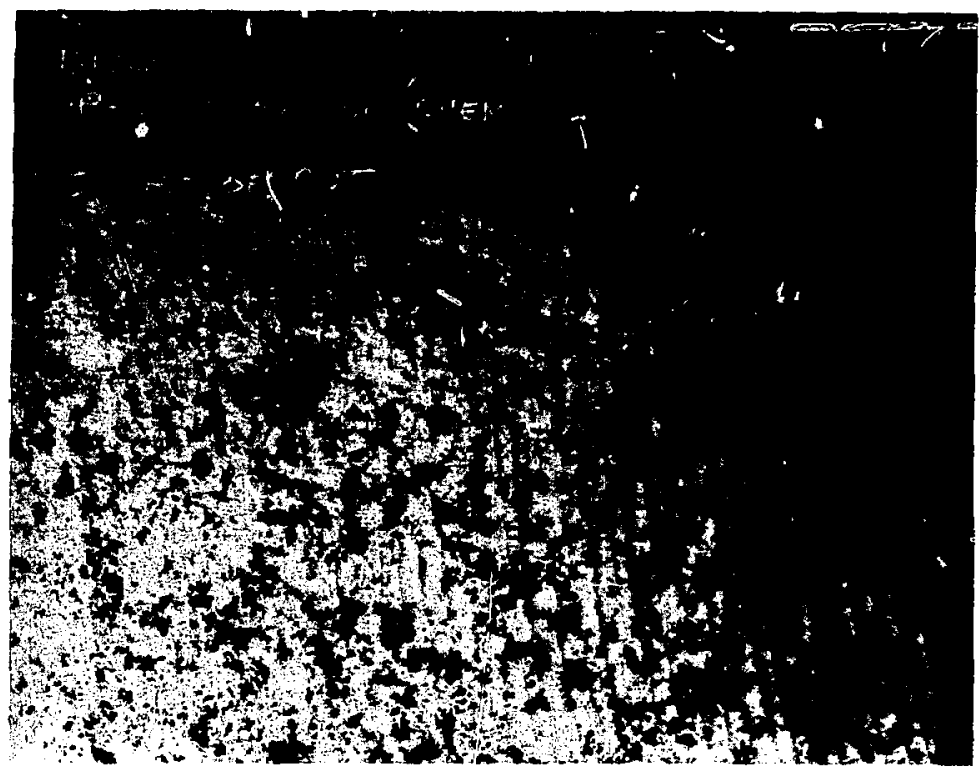

F1g. 21. Disk $G$ surface photomlcrographs. (a) Start of cut, 121X. 


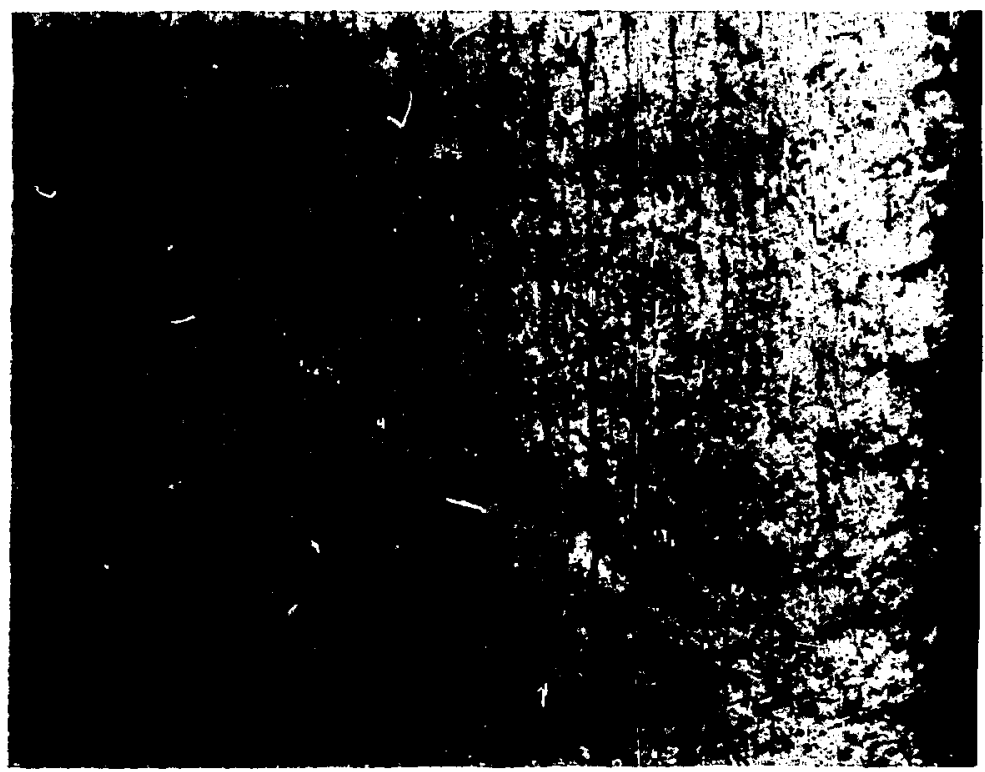

F1g. 21. Disk G surface photomicrographs. (b) End of cut, $121 \mathrm{X}$. 


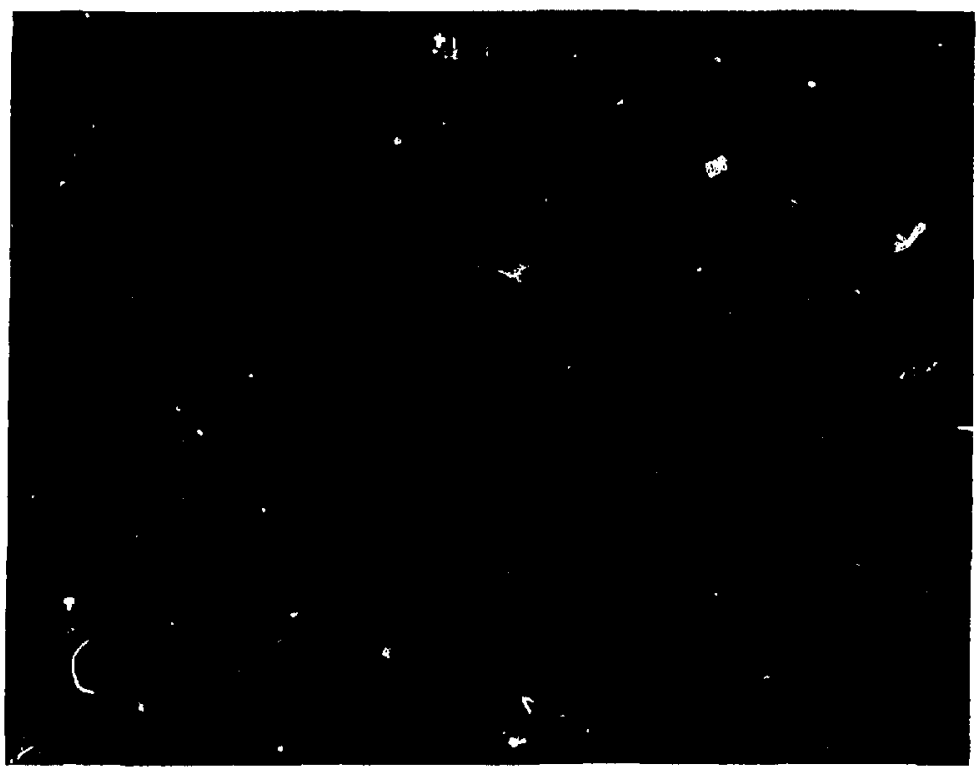

F1g. 22. Disk H surface Interference photomicrographs. (a) Start of cut, $121 \mathrm{x}$.

Disk $\mathrm{H}$ also is an example of the problems inherent in achleving an optical finish on materials made by powder metallurgy. It was assumed that the high-purity material would cause less tool wear and result in a better surface. However, the results Indicited that the absence of Impurity elements did not improve tool life or surface fintsh. Figures $22 \mathrm{a}$ and $22 \mathrm{~b}$ show the surface at a higher magniflcation. Spectfications and the radlograph report are in Appendix c.

The disk test data are glven in tabular form as Table $D-3$ in Appendix $D$. 


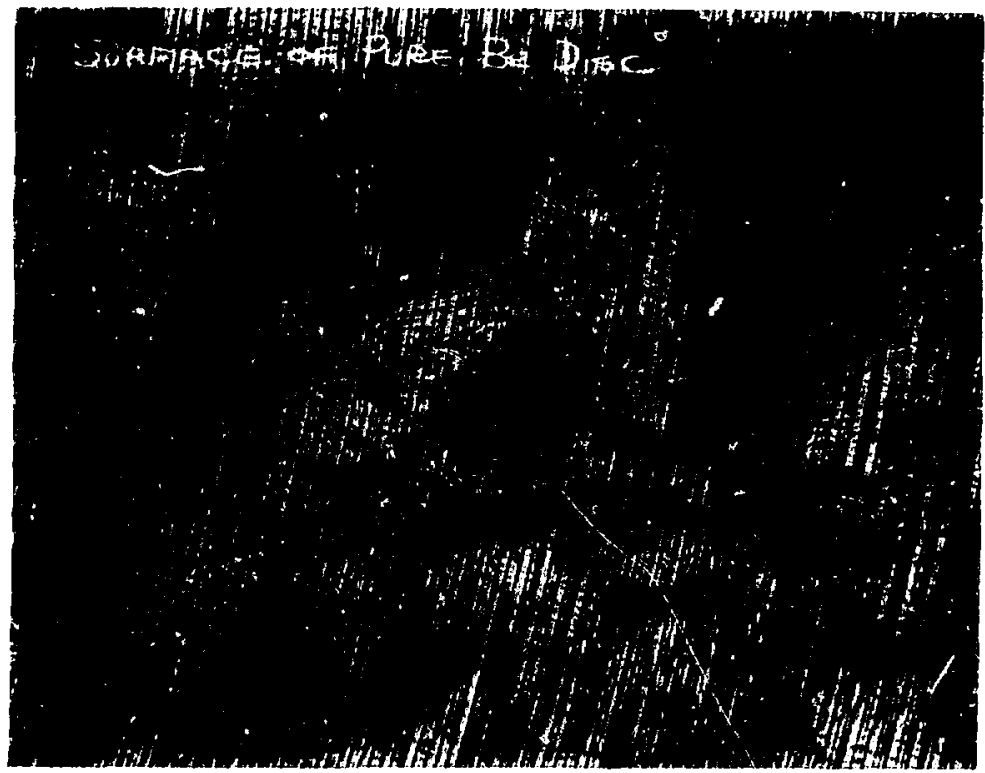

Fig. 22. Disk H surface interference photomicrographs, (b) Typical surface (note grain boundarles), $121 x$. 


\section{Conclusions}

Before making conclustons it is necessary to make a few comments regarding the test procedures.

It is Lawrence Lfvermore Laboratory practice to use theoretical $\mathrm{P} / \mathrm{V}$ values to roughly predict surface finish. The relationship between tool nose radius and feed per revolution determines the theoretical finish desired. The formula uyed is

$$
P / V=\frac{(\text { feed } / \text { revolution })^{2}}{8 \times \text { tool nose radlus }}
$$

Where feed is $0.0013 \mathrm{kn} . / \mathrm{rev}$, and tool nose radius $180.030 \mathrm{in.,}$, for example,

$$
\begin{aligned}
P / V & =\frac{(0.0013)^{2}}{8 \times 0.030}=\frac{1.69 \times 10^{-6}}{0.24} \\
& \simeq 0.00000704 \cong 7 \mu \mathrm{ir} .
\end{aligned}
$$

Peak-to-valley surface fintsh can be checked directly on a clevite analyzer to determine whether the theoretical value has been achieved. Assuming a uniformly random waveform, the AA value is 0.2 times the P/V value (Fig. 23).

$$
\text { An afr-bearing lathe was not }
$$
used in these tests because of contamination problems. Because neither

\begin{tabular}{|c|c|c|c|c|c|c|c|c|c|}
\hline Waveform: $h=1$ & $m_{L}{ }^{*}$ & $m_{M} \cdot$ & AA & rms & $h / A A$ & $\mathrm{~h} / \mathrm{ms}$ & $G / h$ & $G / A A$ & $\mathrm{rms} / \mathrm{AA}$ \\
\hline Uniformly random & -- & $\cdots$ & 0.2 & 0.25 & 5.0 & 4.0 & 0.5 & 2.5 & 1.25 \\
\hline $\begin{array}{l}\text { Round erested } \\
\text { parobolic }\end{array}$ & 0.523 & - & 0.256 & 0.298 & 3.91 & 3.36 & 0.333 & 1.29 & 1.16 \\
\hline $\begin{array}{l}\text { Sharp crested } \\
\text { parabolic }\end{array}$ & 0.770 & --- & 0.256 & 0.298 & 3.91 & 3.36 & 0.687 & 2.60 & 1.16 \\
\hline Sinusaidal & 0.878 & 0.612 & 0.318 & 0.353 & 3.14 & 2.83 & 0.5 & 1.57 & 1.11 \\
\hline Sow tooth & 0.630 & 0.578 & 0.25 & 0.289 & 4.0 & 3.46 & 0.5 & 2.0 & 1.16 \\
\hline Squore & 1.0 & 1.0 & 0.5 & 0.5 & 2.0 & 2.0 & 0.5 & 1.0 & 1.0 \\
\hline
\end{tabular}
diamond-turning machine is presently used for cutting contaminated material, the time and cost involved in

$h_{O L}=M_{L} h_{;} h_{O M}=M_{M} h$.

Fig. 23. Average height values for various waveforms. This figure shows the relationshtp between $P / V$ values and $A A$ and rms values. 
adapting these machines for contaminated material cutting was considered excessive unless it were established that addj.tional accuracy wos needed.

Freon TF was used as a coolant becacie it was found to be successful In other machinability tests performed here at Lawrence Livermore Laboratory. It was found to be as good a cutting fluid as carbon tetrachloride, whic: was banned berause of health hazards. Freon TF dres not promote oxidation on the surface of the beryllium, as does water, and leaves the surface clean and free of contamination. It also prevented the buflt-up edge from forming on the diamond tool and provided considerable cooling. The pieces were chilled to the touch at the end of each cut from the raptd evaporation of the Freon.

The $f\lrcorner n i s h$ on the brass disks was nizt of the surface quality that could be obtained on the diamond-turning machine with the air-bearing spindle. However, the flrilsh was good enough to determine whether or not diamond turning was feastble. $i t$ is noteworthy that when the slower feed rates were used to obtain a 0.5-pin. (0.127- $\mu$ ) $P / V$ theoretical finish, the diamond tools were unable to make a cut all the way across the face of the berylliun disk without early fallure. Tool wear was in all cases the governing factor, except on the brass-disk cuts.

It is generally not good practice to use form error as an Indicator of tool wear because such things as chucking Influences and machine travel. errors can also affect form. By comparing the flatness of the sample disks it is possible to estimate the differences of wear rates, verify the earlier findings, and correlate flank wear. The form errors and finishes of the disks cut with Megadiamond can then be compared with those cut with a single-crystal diamond. It Is seen that although the Megadiamond wears slightl, faster, it tends to cut longer because it is continuously exposing fresh diamond to the cutting surface as the tool wears. It is also noteworthy that the carbide tool produced the least form error.

The conclusion that can be drawn based on these tests may be simply stated: diamond tools cannot presently provide optical fintshes on beryllium. This must be qualifier somewhat because there was marginal success for very short distances in achieving theoretical inishes. Surface finish at the start of the cut was of ten the theoretical ralue to which the machine 
had been set. However, because of tool wear, most of the fintshes had sufficiently degraded by the time the end of the cut was reached to be no better (and often worse) than the finish provided by a carbide tool.

The most successful citt obtained was on D1sk $G$, which had been chem1cally milled $0.005 \mathrm{in}$. $(0.127 \mathrm{~mm})$ off each face. We first thought that the reason for the success was that purer bery - Ium resulted from etching.
However, the next test on Disk $H$ served to disprove this theory. D1sk $H$ was of a higher purfty and showed no high-density inclusions in the radlograph (Appendix $\mathrm{C}$ ), yet caused tool wear equal to that caused by the HP-21 beryllium disks. The chemically milled beryllium seemec to smear as the tool dulled and appeared to give a better finish throughout the cut. close cbservation of this surface under a microscope tends to verffy this (Figs. 21 and 22).

\section{Recommendations}

It is recommended that, money and time permitting, the study of wear mecharics on diamond tools be continued. The satisfactory turning of an optical finish on berylltum would be anly one valuable result. Other materials not previously machinable with diamond tools, i.e., steel and other ferrous materlals, may be successfully finlshed also.

In these tests, the theory of graphitization was neither proved nor disappraved. (See Refs. 3, 4, and 5 for discussion of this theory.) Although the tests tend to confirm the theory, the mechanics of wear are still rea:ly unluown. It would be beneficlal to all forms of machining using diamond-turning techniques to know what the wear mechanics are and whether or not it is possible to somehow eliminate the cause of wear or prepare or modify the material to make dlamond-turning feastble. 


\section{References}

1. G. J. London, V. V. Damino, and H. Conrad, "Microstrain Compression of Beryllium Alloy Single Crystals Parallel to the (0001)," Trans. AIME 242, 979 (1968).

2. D. McLean, "The Plastlc Behavicr of Beryllium and Some Other Metals," Conference International Sur La Metallurtgie du Beryllium, Grenoble, France, 1965.

3. A. J. Pekelharing, "Built-up Edge (BUE): Is the Mechanism Understood?" CIRP 23/2 (1974).

4. R. Komanduri and M. C. Shat, "Wear of Synthetic Diamond wher Grinding Ferrous Metals," Nature 255, 211 (1975).

5. C. A. Brookes, "The Friction of Diamond at Elevated Temperatures and Its Interfactal Reactions with Steel," Industrial Diamond Review, 21 (January 1971). 


\section{Appendix A. HP-21 Log Analysis}

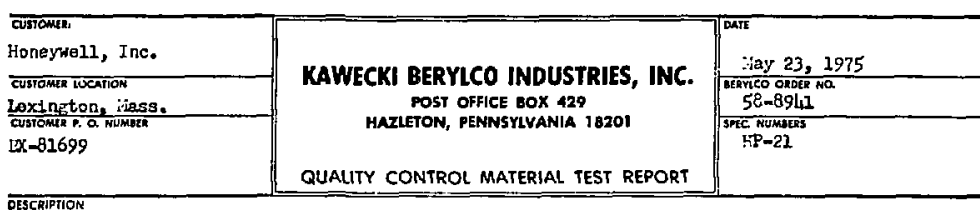

1 PC. Kaseck1 Sorylco Je metal s.od $l_{i}^{\prime \prime}$ jha. $x 3^{\prime \prime}$ lon ${ }_{i}$.

K.E.I. UHITif 5 TIP

K.B.I. FIIS: :isti-9098

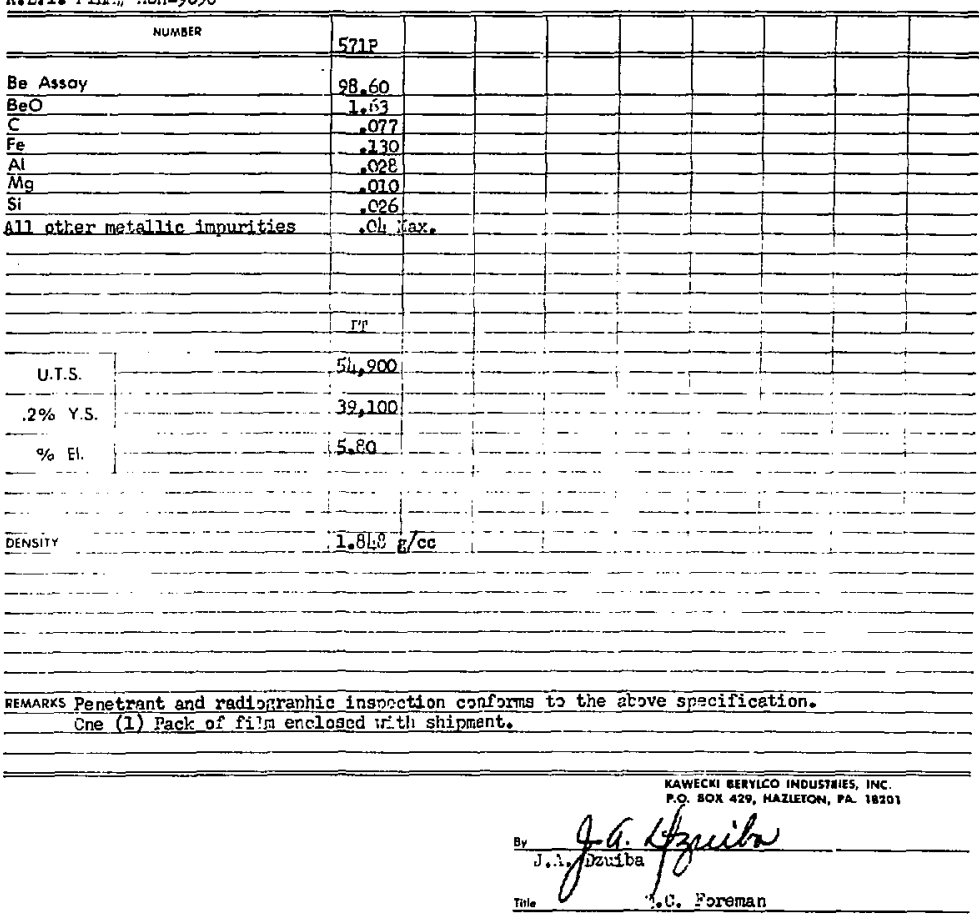




\section{Appendix B. HP-21 Radiograph and Nondestructive Test Report}

Interdepartmental letferhead

Marstation L- 415

Ext:

7601

MEMORANDUM - September 8, 1975

Reference No. 27805

T0: Jim Bryan

FROM: Nondestructive Testing Section

Materials Engineering Division

SUBJECT: Beryllium Specimen

\section{Radiographic Inspection}

No evidence of any abnormality is detected either by dye penetrant or radiographic inspection.

The sample contains an estimated $120 \mathrm{high}$ density inclusions, the largest about .23nm in diameter.

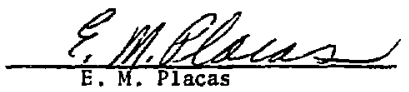

EMP : $c 1 w$

cc: P. Landon 


\section{Appendix C. Specifications and Analysis of Pure Beryllium}

\begin{tabular}{|c|c|c|}
\hline $\begin{array}{l}\text { customis } \\
\text { Untvers1ty of calforita }\end{array}$ & \multirow{4}{*}{ 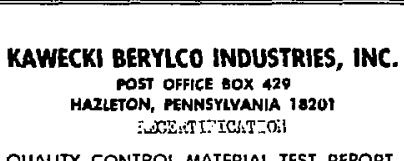 } & \multirow{2}{*}{ 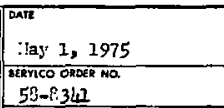 } \\
\hline $\begin{array}{l}\text { CUSToma Lochion } \\
\text { Live more, Gallifornia }\end{array}$ & & \\
\hline $\begin{array}{l}\text { TMER P. O. NUMESR } \\
8305\end{array}$ & & SPEC NUWDisis \\
\hline & & $99.8 \%$ varity \\
\hline
\end{tabular}

OFSCRIPTION

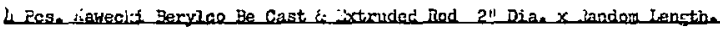

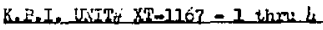

Total Inahes lin:"

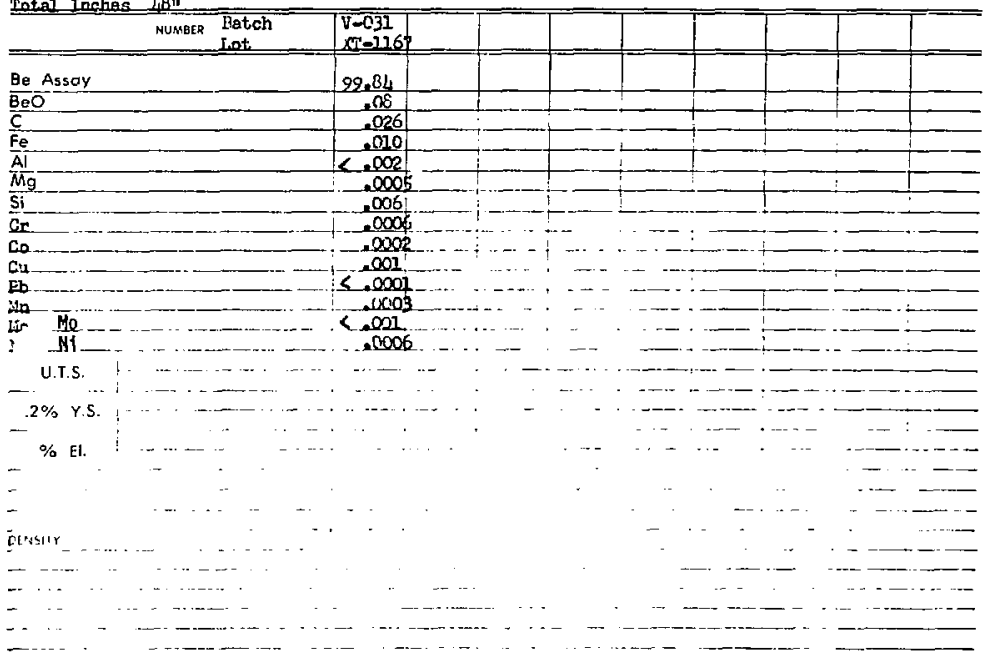

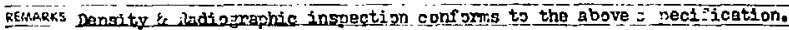

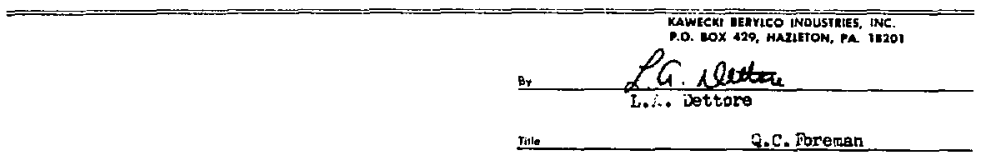




\section{LAWRENCE LNERMORE LABOIZATORY}

Kag 30, 1975

\section{X-BUY FLUURESCENGE ANALYSIS}

SAMPLES: $\quad$ XP-498 KBI Beryllium rods XI-1167 58-8341

REPUESTCR: Rlchard Becker

ANALYSIS REQUESTED: Semi-quantitative eatimate of impurities present Rasuirs: The only impurities observed are those listed below. With the onalysis procedure used, the elements with the approximate $\mathrm{Z}$ range of 24-42, plus $\mathrm{W}, \mathrm{Ta}$, $\mathrm{Pb}$, and $\mathrm{J}$, would be observed at the trace lovel. The rods were washed with nitric acid before the analysis to elelminate surface contaimination.

\begin{tabular}{|c|c|c|c|c|c|}
\hline & $\underline{G}$ & $\mathrm{Fe}$ & $\mathrm{N1}$ & Qu & Ni \\
\hline $\operatorname{Rod} * 1$ & $420 \pm 100$ & $195 \pm 25$ & $65 \pm 10$ & $<30$ & $195 \pm 10$ \\
\hline$R \propto d 2$ & $<50$ & $195=25$ & $80 \pm 10$ & $\leq 20$ & $<5$ \\
\hline $\operatorname{Rod} \# 3$ & $<50$ & $220+25$ & $225 \pm 20$ & $\leq 20$ & $<5$ \\
\hline $\operatorname{Rod}: 44$ & $<50$ & $105 \pm 20$ & $85+10$ & $\leq 20$ & $<5$ \\
\hline
\end{tabular}

KBTHOD; Fnergy dispersive spectrometer, $W$ tube $+\mathrm{Sn}$ filter. Quantitation obtained from boron carbide standards, corrected for matrix absorption differences.

Anglyst: Richard Ryon 
interdepartmental rentritead

MarStationL- 415

Ext:

7601

MEMDRANDUM - September 10, 1975

Reference No. 27823

TO:

H. W. Hauschildt

FROM: Nondestructive Testing Section

Materials Engineering Division

SUEJECT: BERYLLIUM SPECIMEN

ITEMS: 2

Radiographic Inspection

The one minimal high density inclusion noted is probably surface contamination.

The mottled appearance seen is probably a diffraction pattern resulting from enlarged grain size.

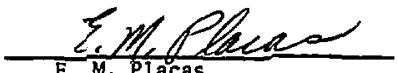

EMP : $c l w$

cc: P. Landon 
Table J-1. Results of facing cuts.

\begin{tabular}{|c|c|c|c|c|c|c|c|c|c|c|c|}
\hline \multirow{2}{*}{$\begin{array}{l}\text { Test } \\
\text { No. }\end{array}$} & \multirow[b]{2}{*}{ Tool material } & \multicolumn{2}{|c|}{ Speed } & \multicolumn{2}{|c|}{ Feed } & \multirow{2}{*}{$\begin{array}{l}\text { Deptli } \\
\text { of } \\
\text { cut, in. }\end{array}$} & \multirow{2}{*}{$\begin{array}{l}\text { Cutting } \\
\text { fluid }\end{array}$} & \multirow{2}{*}{$\begin{array}{l}\text { Flank } \\
\text { wear } \\
\text { land, in. }\end{array}$} & \multicolumn{2}{|c|}{ P/V surface flnish } & \multirow[b]{2}{*}{ Remarks } \\
\hline & & rpm & $\operatorname{sfm}^{\mathrm{a}}$ & in. $/ m i n$ & 1n./rev. & & & & Theor., uin. & $\begin{array}{l}\text { Acteval } 1 \text {. } \\
\text { range, } 1 \text {. }\end{array}$ & \\
\hline 1 & $\begin{array}{l}\text { Moore gingle- } \\
\text { crystal diamond } \\
\text { Nh-44, 0.030- } \\
\text { in. radius }\end{array}$ & 900 & 350 & 0.320 & 0.0035 & 0.001 & vry & 0.0021 & 0.5 & $2-130$ & $\begin{array}{l}\text { Diamond tool chipped } \\
\text { during initial contact }\end{array}$ \\
\hline 2 & $\begin{array}{l}\text { Moore single- } \\
\text { crystal diamond } \\
0 \text { tL-44, 0.030- } \\
\text { in, radius } \\
\text { (new position) }\end{array}$ & 375 & 145 & 0.130 & 0.0034 & 0.001 & Dry & 0.0027 & 0.5 & $5-130$ & $\begin{array}{l}\text { Slower speed didn't } \\
\text { help much }\end{array}$ \\
\hline 3 & $\begin{array}{l}\text { Moore single- } \\
\text { crystal d amond } \\
\text { JL-42, } 0.030- \\
\text { In. radius }\end{array}$ & 375 & 145 & 0.130 & 0,0034 & 0.001 & Dry & 0.0023 & 0.5 & $5-130$ & $\begin{array}{l}\text { Repeatabllity of test } \\
\text { uich different diamend } \\
\text { tool. }\end{array}$ \\
\hline 4 & $\begin{array}{l}\text { Carbide grade } \\
907\end{array}$ & 750 & 290 & 0.600 & 0.0008 & 0.001 & Dry & 0.0016 & 3 & $20-50$ & $\begin{array}{l}\text { Standard prectsion finish } \\
\text { using carbide }\end{array}$ \\
\hline 5 & $\begin{array}{l}\text { Moore single- } \\
\text { crystal diamond } \\
\text { \#E-4, o.030- } \\
\text { in. radius }\end{array}$ & 200 & 39 & 0.230 & 0.0013 & 0.0005 & Freon IF & 0.0018 & 7 & $2-30$ & $\begin{array}{l}\text { Freon TF was of } \\
\text { significant value as a } \\
\text { cuteing fluid }\end{array}$ \\
\hline 6 & $\begin{array}{l}\text { Megadiamond, } \\
0.007-1 n . \\
\text { radiue, } \\
\text { unlapped } \\
\text { corner very } \\
\text { rough }\end{array}$ & 100 & 39 & 0.130 & 0.0013 & 0.001 & Freon TF & 0.0041 & 32 & $60-120$ & $\begin{array}{l}\text { Poot finish probably due } \\
\text { to nose-radius quality }\end{array}$ \\
\hline
\end{tabular}

$a_{s f t}=$ surface $\mathrm{ft} / \mathrm{min}$. 
Table D-2. Results of longltudinal turning cuts.

\begin{tabular}{|c|c|c|c|c|c|c|c|c|c|c|c|c|}
\hline \multirow[b]{2}{*}{$\begin{array}{l}\text { Test } \\
\text { No. }\end{array}$} & \multirow[b]{2}{*}{ Tool material } & \multicolumn{2}{|c|}{ Speed } & \multicolumn{2}{|c|}{ Feed } & \multirow{2}{*}{$\begin{array}{l}\text { Depth } \\
\text { of } \\
\text { cut. in. }\end{array}$} & \multirow[b]{2}{*}{$\begin{array}{l}\text { Cutting } \\
\text { fluid }\end{array}$} & \multirow[b]{2}{*}{$\begin{array}{l}\text { Cutting } \\
\text { time, } 5\end{array}$} & \multirow{2}{*}{$\begin{array}{l}\text { Flank } \\
\text { wear } \\
\text { land, it: }\end{array}$} & \multirow{2}{*}{\multicolumn{2}{|c|}{$\frac{P / \mathrm{l} \text { surface fintsh }}{\text { Theor, win. ramge, Hin. }}$}} & \multirow[b]{2}{*}{ Remarks } \\
\hline & & rpm & $\operatorname{sen}^{2}$ & $\ln \cdot \ln i n$ & in. $/ x \in u$. & & & & & & & \\
\hline 1 & $\begin{array}{l}\text { Megadianond A, } \\
\text { upper lefe } \\
\text { corner, } 0.015 \text { - } \\
\text { In. tadius }\end{array}$ & 100 & 39 & 0.105 & 0.00105 & 0.001 & Freon TF & $\begin{array}{r}10 \\
20 \\
40 \\
100 \\
200 \\
500\end{array}$ & $\begin{array}{l}0.001 \\
0.002 \\
0.002+ \\
0.003 \\
0.005 \\
0.0093\end{array}$ & & & Heat Test No. 1, 100 tpm: \\
\hline 2 & $\begin{array}{l}\text { Hegadiatrond A, } \\
\text { upper right } \\
\text { corner, } 0.015- \\
\text { in. radius }\end{array}$ & 30 & 11.1 & 0.105 & 0.0035 & 0.001 & Freon TF & $\begin{array}{r}10 \\
25 \\
50 \\
100 \\
200 \\
500 \\
1500 \\
2400\end{array}$ & $\begin{array}{l}0.0015 \\
0.0025 \\
0.003 \\
0.003+ \\
0.0033 \\
0.0035 \\
0.0055 \\
0.0092\end{array}$ & & & Wear Test No. 2,30 трл \\
\hline 3 & $\begin{array}{l}\text { Hegadiaind } A \text {, } \\
\text { lower left } \\
\text { corner, } 0.015- \\
\text { la, radius }\end{array}$ & 56 & 25.7 & 0.105 & 0.0016 & 0.001 & Freon TF & $\begin{array}{r}10 \\
20 \\
50 \\
100 \\
200 \\
500\end{array}$ & $\begin{array}{l}0.0015 \\
0.0025 \\
0.0035 \\
0.004 \\
0.005 \\
0.0082\end{array}$ & & & Wear Test No. 3, $66 \mathrm{rpm}$ \\
\hline 4 & $\begin{array}{l}\text { Megad I amond A, } \\
\text { lover I Lght } \\
\text { corner, } 0.015- \\
\text { 1n. radlus }\end{array}$ & 20110 & 780 & 3.2 & 0.0016 & 0.001 & Freon TF & $\begin{array}{l}10 \\
20\end{array}$ & $\begin{array}{l}0.0045 \\
0.0068\end{array}$ & & & $\begin{array}{l}\text { Wear Test No. 4, } 2000 \mathrm{rpm} \text {, } \\
=1.1-1 \mathrm{n} \text {. length of cue }\end{array}$ \\
\hline 5 & $\begin{array}{l}\text { Megadlanond } B \text {, } \\
\text { upper left } \\
\text { corner, } 0.015- \\
\text { In. redius }\end{array}$ & 30 & 11.7 & 0.070 & 0.0023 & 0.001 & $\begin{array}{l}\text { Freeze-lt } \\
\text { (mpray } \\
\text { Freon tn } \\
\text { aerosol } \\
\text { can) }\end{array}$ & $\begin{array}{r}10 \\
20 \\
50 \\
100 \\
200\end{array}$ & $\begin{array}{l}0.002 \\
0.702 \\
0.002 \\
0.002 \\
0.003\end{array}$ & & & $\begin{array}{l}\text { Fffect of }-50^{\circ} \mathrm{F} \text { cooling } \\
\text { (ran out of Freeze-IE) }\end{array}$ \\
\hline A & $\begin{array}{l}\text { Negad Iamond } B, \\
\text { upper tight } \\
\text { corner, 0.015- } \\
\text { 17. radiug }\end{array}$ & 50 & 19.5 & 0.070 & 0.0014 & 0.0015 & Freon $T F$ & $\begin{array}{r}600 \\
1800\end{array}$ & $\begin{array}{l}0.006 \\
0.0103\end{array}$ & & & $\begin{array}{l}\text { Cleanup cut to obtain } \\
\text { constant } 0 . d \text {. on log and } \\
\text { obtaln addicional point } \\
\text { on cool-11fe curve }\end{array}$ \\
\hline
\end{tabular}

$a_{s \mathrm{fm}}=$ surface $\mathrm{ft} / \mathrm{gin}$. 
Table D-2. Results of longltudinal turning cuts (cont.).

\begin{tabular}{|c|c|c|c|c|c|c|c|c|c|c|c|c|}
\hline \multirow{2}{*}{$\begin{array}{l}\text { Test } \\
\text { No. }\end{array}$} & \multirow[b]{2}{*}{ Tool material } & \multicolumn{2}{|c|}{ Speed } & \multicolumn{2}{|c|}{ Feed } & \multirow{2}{*}{$\begin{array}{l}\text { Depth } \\
\text { of } \\
\text { cut, in. }\end{array}$} & \multirow{2}{*}{$\begin{array}{l}\text { Cutting } \\
\text { fluid }\end{array}$} & \multirow{2}{*}{$\begin{array}{l}\text { Cucting } \\
\text { time, s }\end{array}$} & \multirow{2}{*}{$\begin{array}{l}\text { FI ank } \\
\text { wear } \\
\text { land, } \mathrm{ia} .\end{array}$} & \multicolumn{2}{|c|}{$P / V$ surface finish } & \multirow[b]{2}{*}{ Remarks } \\
\hline & & rpm & $\mathbf{s f m} \mathrm{m}^{\mathrm{a}}$ & $\operatorname{in} . / \mathrm{min}$ & in. /rev. & & & & & Thieor., Hin. & $\begin{array}{c}\text { netual } \\
\text { range, Hin. }\end{array}$ & \\
\hline 6 & $\begin{array}{l}\text { Megadlamond } B \text {, } \\
\text { lower right } \\
\text { comer, 0.015- } \\
\text { ln. radius }\end{array}$ & 66 & 25.7 & 0.070 & 0.001 & 0.001 & Freon TF & 400 & 0.0056 & 8 & $25-80$ & $\begin{array}{l}\text { Best-finish effort with } \\
\text { Megatianond and slowest } \\
\text { possible feed }\end{array}$ \\
\hline 7 & $\begin{array}{l}\text { Noore single- } \\
\text { crystal } \\
\text { dlanond }\end{array}$ & 66 & 25.7 & 0.070 & 0.001 & 0.00075 & Freon TF & 400 & 0.006 & 4 & $15-100$ & $\begin{array}{l}\text { Camparison of single- } \\
\text { crystal diamond to Mega- } \\
\text { diamond (part showed steep } \\
\text { taper on this section) }\end{array}$ \\
\hline $\begin{array}{l}8 \\
\text { (Fac- } \\
\text { Ing } \\
\text { cur) }\end{array}$ & $\begin{array}{l}\text { Moore single- } \\
\text { crystal dianond } \\
\text { be-3 }\end{array}$ & 66 & 25.7 & 0.02 .4 & 0.0036 & 0.001 & Frean $\mathrm{TH}$ & 10,500 & Sec remark & 0.5 & $5-70$ & $\begin{array}{l}\text { Tool fallure led to hiph } \\
\text { enough cool pressure that } \\
\text { tool brake at } 17.5 \mathrm{~min}\end{array}$ \\
\hline 9 & Megadfamond B & & & & & & $\mathrm{I}_{2}$ & & & & & $\begin{array}{l}\text { Could not get } \mathrm{LN}_{2} \text { :o work } \\
\text { correctly; test stopped }\end{array}$ \\
\hline 10 & $\begin{array}{l}\text { Negadiamond B, } \\
\text { lower left } \\
\text { comer, } 0.015- \\
\text { in. radiug }\end{array}$ & 30 & 11.7 & 0.070 & 0.0023 & 0.001 & $\begin{array}{l}\text { Mero- } \\
\text { duste: } \\
\text { Inverced } \\
\text { to spray } \\
\text { Freon at } \\
-50^{\circ} \mathrm{F}\end{array}$ & $\begin{array}{r}10 \\
20 \\
50 \\
100 \\
400\end{array}$ & $\begin{array}{l}0.002 \\
0.002 \\
0.0025 \\
0.0113 \\
0.007\end{array}$ & & & $\begin{array}{l}\text { Repeat of test No. } 5 \text { to } \\
\text { continue time period to } \\
400 \mathrm{~s} \text { (used } 3 \text { cang of } \\
\text { spray) }\end{array}$ \\
\hline 11 & $\begin{array}{l}907 \text { grade } \\
\text { carbide tool, } \\
\text { o.030-1n. } \\
\text { radius }\end{array}$ & 500 & 195 & 1.100 & 0.0022 & 0.001 & Dry & 95 & 0,002 & & $\begin{array}{l}20-50 \text { not } \\
\text { including } \\
\text { material } \\
\text { flaws }\end{array}$ & $\begin{array}{l}\text { Cleanup cut on loB } \\
\text { dianeter }\end{array}$ \\
\hline $\begin{array}{l}12 \\
\text { (Fac- } \\
\text { Ing } \\
\text { cut) }\end{array}$ & $\begin{array}{l}907 \text { grade } \\
\text { carbide, } \\
0.030-i n . \\
\text { radius }\end{array}$ & 100 & 39 & 0.130 & 0.9013 & 0.001 & $\begin{array}{l}\text { l'erk } \\
\text { (perchlor }\end{array}$ & (hylene) & 0.003 & 7 & $15-65$ & $\begin{array}{l}\text { Carbide tool used at } \\
\text { diamond tool speeds and } \\
\text { feeds; not a suecess }\end{array}$ \\
\hline $\begin{array}{l}13 \\
\text { (Fac- } \\
\text { Ing } \\
\text { "cut) }\end{array}$ & $\begin{array}{l}\text { Moore single- } \\
\text { erystal diamond } \\
\text { OL- } 44,0.030- \\
\text { In. radius }\end{array}$ & 100 & 39 & 0.130 & 0.0013 & 0.001 & Prerk & & 0.0059 & 7 & $10-100$ & $\begin{array}{l}\text { Perk not as good as Freon } \\
\text { TF. Parted off 0.25-1n.- } \\
\text { thick disk for SEy and } \\
\text { radiograph. Tool also cut } \\
\text { up for SE! }\end{array}$ \\
\hline
\end{tabular}

$a_{\text {afo }}=$ surface $f t / m i n$. 
Table D-2. Results of longitudinal turning cuts (cont.).

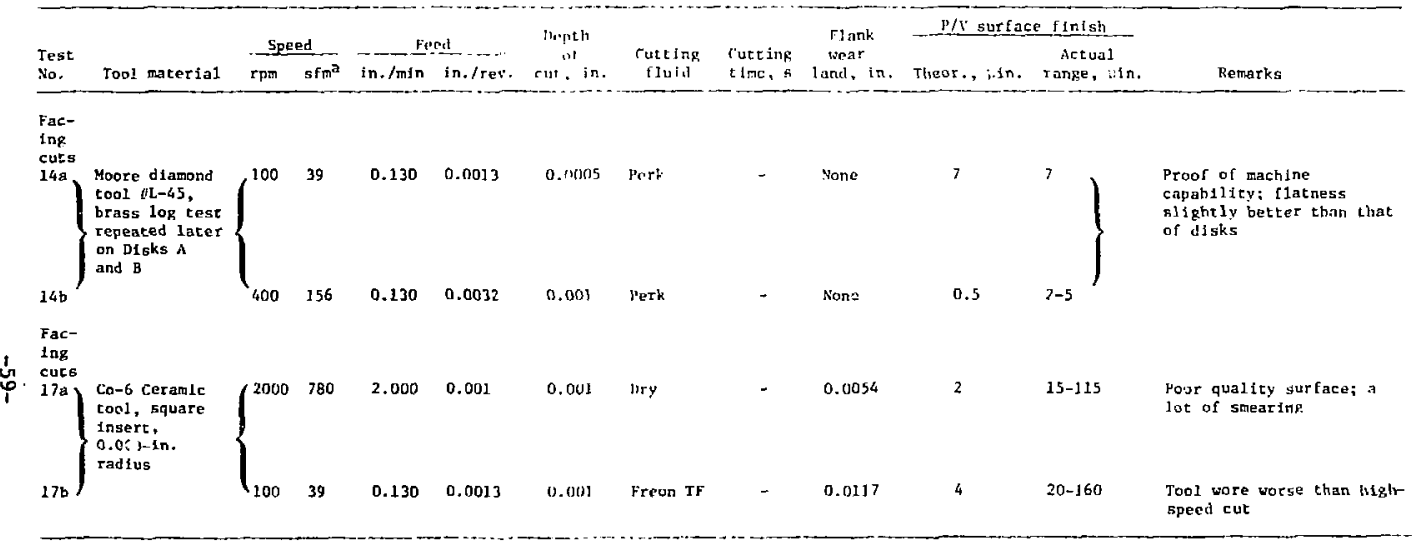

$a_{\text {sf }}=$ surface $f t / m i n$. 
Tat?e D-3. D1sk test data.

\begin{tabular}{|c|c|c|c|c|c|c|c|c|c|}
\hline Dfsk & Disk material & Tool description & $\begin{array}{l}\text { Speed, } \\
\text { rpm }\end{array}$ & $\begin{array}{l}\text { Feed } \\
1 \mathrm{n} . / \mathrm{min}\end{array}$ & $\begin{array}{l}\text { Theor. } \\
\text { P/V, Hin. }\end{array}$ & $\begin{array}{l}\text { Actual } \\
P / V, \mu 1 n \text {. }\end{array}$ & $\begin{array}{l}\text { Part } \\
\text { form, } \\
\text { HIn. }\end{array}$ & $\begin{array}{l}\text { Tool } \\
\text { flank } \\
\text { wear, in. }\end{array}$ & Remarks \\
\hline A & Brass & $\begin{array}{l}\text { Moore single- } \\
\text { crystal diamond } \\
\text { AL-23, } 0.030-1 n \text {. } \\
\text { radius }\end{array}$ & 400 & 0.130 & 0.5 & $\begin{array}{l}2-25 \\
\text { Inc. } \\
\text { mati. } \\
\text { flaws }\end{array}$ & $\begin{array}{l}\text { lor', } \\
\text { concave }\end{array}$ & None & $\begin{array}{l}\text { Best finish possible on } \\
\text { Hardinge Lathe } / \mathrm{L}-325\end{array}$ \\
\hline$B$ & Brass & $\begin{array}{l}\text { Moore single- } \\
\text { crystal diamond } \\
\text { fl-23, 0.030- } \\
\text { fn. radius }\end{array}$ & 100 & 0.130 & 7 & $\begin{array}{l}5-65, \\
\text { inc. } \\
\text { mat } 1 \\
\text { flaws }\end{array}$ & $\begin{array}{l}110 \\
\text { concave }\end{array}$ & None & $\begin{array}{l}\text { Results of slowest machine } \\
\text { feed at } 100 \text { rpm. for com- } \\
\text { parative } 7-\mu 1 n \text {. P/V } \\
\text { surface to beryllium disks }\end{array}$ \\
\hline $\mathcal{C}$ & $\begin{array}{l}\mathrm{HP}-21 \text { beryl11um } \\
\text { as rec'd }\end{array}$ & $\begin{array}{l}907 \text { grade } \\
\text { carbide tool, } \\
0.030-1 \pi . \\
\text { radius }\end{array}$ & 460 & 0.500 & 5 & $20-95$ & $\begin{array}{l}200, \\
\text { concave }\end{array}$ & 0.001 & $\begin{array}{l}\text { Basic surface on which } \\
\text { diamond cuts were made }\end{array}$ \\
\hline D & $\begin{array}{l}\text { HP-21 beryllium } \\
\text { as rec'd }\end{array}$ & $\begin{array}{l}\text { Moore single- } \\
\text { crystal diamond } \\
\text { hL-45,0.030- } \\
\text { In. radius }\end{array}$ & 100 & 0.130 & 7 & $5-95$ & $\begin{array}{l}725 \\
\text { concave }\end{array}$ & 0.0047 & $\begin{array}{l}\text { Tool falled at }=1 \text { in. } \\
\text { diameter typlcal of } \\
\text { Initial facing cut } \\
\text { surfaces }\end{array}$ \\
\hline$E$ & $\begin{array}{l}\text { HP }-21 \text { beryllium } \\
\text { as rec'd }\end{array}$ & $\begin{array}{l}\text { Citco single- } \\
\text { crystal diamond } \\
\# 53,0.030-1 n \text {. } \\
\text { radius }\end{array}$ & 100 & 0.130 & 7 & $10-95$ & $\begin{array}{l}\text { 375, } \\
\text { concave }\end{array}$ & 0.0059 & $\begin{array}{l}\text { Test to see erfect of } \\
\text { different diamond } \\
\text { orientation in mountirg }\end{array}$ \\
\hline $\mathbf{F}$ & $\begin{array}{l}\mathrm{HP}-21 \text { beryllium } \\
\text { as rec'd }\end{array}$ & $\begin{array}{l}\text { Megadlamond } \\
\text { polycrystalline } \\
\text { square insert } \\
\text { "C, } 0.015-1 n \text {. } \\
\text { radius }\end{array}$ & 100 & 0.130 & 14 & $36-70$ & $\begin{array}{l}620 \\
\text { conceve }\end{array}$ & 0.0076 & $\begin{array}{l}\text { Small nose radius and } \\
\text { edge quality result in } \\
\text { poorer Inftial finish }\end{array}$ \\
\hline$G$ & $\begin{array}{l}\text { HP- } 21 \text { beryllium } \\
\text { chenically } \\
\text { milled } 0.005- \\
\text { 1n. of f each } \\
\text { face }\end{array}$ & $\begin{array}{l}\text { Moore single- } \\
\text { crystal diamond } \\
\text { nE-5, } 0.030-i n . \\
\text { radius }\end{array}$ & 100 & 0.130 & 7 & $=-35$ & $\begin{array}{l}725, \\
\text { concave }\end{array}$ & 0.0025 & $\begin{array}{l}\text { Best finish; appears to } \\
\text { have smeared at end of } \\
\text { cut when tool got dull }\end{array}$ \\
\hline $\mathrm{H}$ & $\begin{array}{l}\mathrm{KBI} \\
99.8 \% \text { pure } \\
\text { bery111um }\end{array}$ & $\begin{array}{l}\text { Moore single- } \\
\text { crystal diamond } \\
\text { fE-5, 0.030- } \\
\text { in. radius }\end{array}$ & 100 & 0.130 & 7 & $10-90$ & $\begin{array}{l}780, \\
\text { concave }\end{array}$ & 0.0024 & Porous appearance \\
\hline
\end{tabular}

